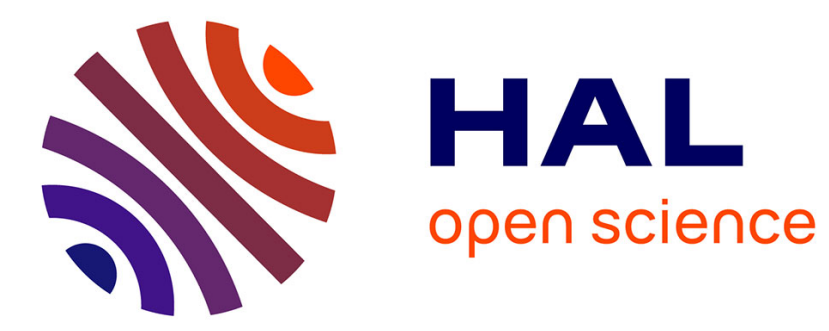

\title{
Shore platform lowering due to frost shattering during the 2009 winter at Mesnil-Val, English Channel coast, NW France
}

Thomas Dewez, V Regard, A Duperret, E Lasseur

\section{- To cite this version:}

Thomas Dewez, V Regard, A Duperret, E Lasseur. Shore platform lowering due to frost shattering during the 2009 winter at Mesnil-Val, English Channel coast, NW France. Earth Surface Processes and Landforms, 2015, pp.XX-XX. 10.1002/esp.3760 . hal-01163400

\author{
HAL Id: hal-01163400 \\ https://hal.science/hal-01163400
}

Submitted on 12 Jun 2015

HAL is a multi-disciplinary open access archive for the deposit and dissemination of scientific research documents, whether they are published or not. The documents may come from teaching and research institutions in France or abroad, or from public or private research centers.
L'archive ouverte pluridisciplinaire HAL, est destinée au dépôt et à la diffusion de documents scientifiques de niveau recherche, publiés ou non, émanant des établissements d'enseignement et de recherche français ou étrangers, des laboratoires publics ou privés. 


\title{
Shore platform lowering due to frost shattering during the 2009 winter at Mesnil-Val, English Channel coast, NW France
}

\author{
T. Dewez ${ }^{1}$, V. Regardd,3,4,", A. Duperret ${ }^{5}$, E. Lasseur ${ }^{1}$, \\ 1. BRGM ; Direction of Risks and Mitigation, 3 avenue C. Guillemin, F-45060 Orleans-La Source, France \\ 2. Université de Toulouse ; UPS GET, 14 avenue E. Belin, F-31400 Toulouse, France \\ 3. CNRS ; GET ; 14 avenue E. Belin, F-31400, Toulouse, France \\ 4. IRD ; UR 234, GET ; 14 avenue E. Belin, F-31400, Toulouse, France \\ 5. UMR CNRS 6294 LOMC - Université du Havre, Laboratoire Ondes et Milieux Complexes, 53, rue de \\ Prony, BP 540 - 76058 Le Havre Cedex, France. \\ * corresponding author
}

\begin{abstract}
In 2008-2009, a severe cold snap affected the otherwise temperate mid-latitude coasts of the English Channel of France. In March 2009, we gathered rock spalling observations at Mesnil Val, NW France, to document the effect of frost on platform lowering in macro-tidal environments. Six epochs of frost were recorded in two months, the two longest lasted 16 and 8 days, with minimum air temperature dropping to $-9.5^{\circ} \mathrm{C}$. Semi-diurnal tides flood the entire platform, imposing up to 25 freeze-thaw cycles below $-2.5^{\circ} \mathrm{C}$, the freezing temperature of seawater. 19 cycles occurred at neap tidal elevation lasting at most $3.5 \mathrm{hrs}$. Our integrated observations indicate that these frost cycles were responsible for a platform lowering of about $0.8 \pm 0.5 \mathrm{~mm}$ during a single winter. No clear spatial trend appears, nor do macroscopic chalk types clearly stand out as being more susceptible to erosion. Assuming that the longterm platform retreat model preserves a constant slope, frost shattering would then account for 10 to $20 \%$ of the expected annual platform erosion rate. Under more contrasted climates, frost is thus likely to be a prominent shaping process for rocky coastal platforms.
\end{abstract}

Keywords: Shore platform lowering/erosion; freeze-thaw cycles; chalk coast; English Channel; Normandy

\section{Introduction}

Frost shattering has some influence on shore platform erosion; it is controlled by the ambient temperature and modulated by tide buffering (e.g., Harris and Ralph, 1980; Robinson and Jerwood, 1987a, 1987b; Trenhaile and Rudakas, 1981). Frost shattering is a generic term we use to describe the brecciation effect of frost on a rock surface. It has been recognized as a significant morphological agent of shore platform development in cold environments like Quebec and Norway (e.g., Aarseth and Fossen, 2004; Daigneault et al., 2004; Matthews et al., 1986; Trenhaile and Rudakas, 1981), but under the coastal temperate climates of Western Europe bathed by the Gulf Stream, frost events are more rare. One could therefore wonder what its contribution is to shore platform lowering processes in that context. There have been documented occurrences of chalk platform damage induced by frost shattering in the United Kingdom (Harris and Ralph, 1980; Moses et al., 2006; Robinson and Jerwood, 1987b). Robinson and Jerwood (1987a, 1987b) explored chalk shores of southern England after the harsh 1985 and 1986 winters and found severe rock damage, mainly located around the high tide water level, well above the seaweed covered platform (-1.25 m NGF69 in our study area). In this paper, we document the effect of frost on rock brecciation, after the 2008-2009 winter on the coastal platform of Mesnil-Val (English Channel coast of north-western France, $50^{\circ} 03^{\prime} \mathrm{N}, 1^{\circ} 20^{\prime} \mathrm{E}$ ). The purpose of this article, beyond a simple opportunistic descriptive and quantitative study, is to discuss the relative contribution of frost compared to other already quantified erosion processes at this temperate macrotidal coastal platform (e.g., Costa et al., 2004; Dewez et al., 2013; Duperret et al., 2002, 2004; Regard et al., 2012, 2013).

The action of frost is recognizable by shallow scars left on the platform and cliff during winter periods (cf. Dewez et al., 2013; Robinson and Jerwood, 1987b). They differ morphologically from abrasion cupules left by pebbles impact with their sharp edges and large detachment surface. Frost spalling scars occur ubiquitously on the platform beyond the limit of $40 \mathrm{~m}$ from cliff base where pebble impact is confined (e.g., Regard et al. 2013).

The processes driving the detachment of rock particles by frost action are debated. Some argue in favor of freeze-thaw cycles in saturated conditions on tidal shore platforms (Robinson and Jerwood, 1987a, 
1987b) others suggest ice segregation formation, usually observed beneath permafrost (Murton et al., 2006) or within water saturated fractures (Matsuoka and Murton, 2008) is important. The mechanical processes driven by frost are microgelivation in unsaturated rocks with slow seasonal freezing and macrogelivation within jointed rocks close to saturation under fast freezing (Matsuoka, 2001). Two main processes of frost weathering have been distinguished: volumetric expansion and ice segregation (Matsuoka and Murton, 2008). Low temperatures contract the rock while freezing pore water freezes and dilates. These antagonist stresses add up to break pore walls and establish micro-crack networks in the rock matrix. Laboratory experiments have quantified rock behavior under freezing conditions as a function of the rock porosity and water saturation. Rocks with a total porosity lower than $6 \%$ are not frost sensitive (Lautridou and Ozouf, 1982; Prick, 1997). Rocks with a multimodal porosity which are not saturated commonly undergo thermal contraction when frozen. This is due to the unfrozen water anisotropic migrations fromone pore to the next and cryosuction process, whereas rocks with unimodal porosity expand when water-saturated under the effect of water transformation to ice (Prick, 1995, 1997). Another explanation using hydrofracturing can be proposed. The high pore-water pressures needed for hydrofracture may arise from pore-water expulsion in water-saturated rocks, with large and interconnected pores or where large hydraulic gradients exist (Matsuoka and Murton, 2008). Cracks then progressively grow larger, coalesce and loosen pieces of rock. Large surface ruptures of several square centimeters observed in nature in Chalk may be produced using multi-scale competition between volumetric expansion and ice segregation in the chalk matrix (high porosity range) and hydrofracturing under water-saturated conditions in association with volumetric expansion in macroscopic joints.

Ice segregation can explain the cause and dynamics of macro-crack development (Delunel et al., 2010; Matsuoka and Murton, 2008; Murton et al., 2006). Micro-cracks initiate with freezing pore water, but once micro-cracks have fractured pore walls, cracks grow and propagate because frozen water kernels grow into lenses. Ice lens thickening is fed by sucking up liquid water in their vicinity due to capillary forces. Once the immediate neighborhood of ice lenses is depleted with water, liquid water migrates along the micro-crack network (Murton et al., 2006) and cracks dimensions can grow exponentially as more liquid water is drawn in and subsequently freezes. These segregation ice lenses can thus pry macro-cracks open in a matter of a few freeze thaw cycles without needing confinement nor pore water saturation (Murton et al., 2006). Even with 65\% rock-water saturation macro-cracks can form. Segregation ice only requires liquid water around frozen kernels, which can be the case on a shore platform as sea-water freezes at lower temperature $\left(-2.5^{\circ} \mathrm{C}\right)$ than fresh water $\left(0^{\circ} \mathrm{C}\right)$, capillary suction of liquid water can thus act for longer periods, if temperature drops below $-2.5^{\circ} \mathrm{C}$. The only pre-condition is an established crack network.

Close-up views of the cliff affected by frost brecciation exhibit such a network, parallel to the cliff face (Figure 1). Segregation ice lenses form parallel to the cool rock surface. On the cliff, they build in vertical flakes parallel to the cliff face. On the platform, they will be horizontal. In the platform, cracks will exploit weak mechanical sedimentary discontinuities like thin clay bands (as observed by Robinson and Jerwood, 1987b). In Murton et al.'s experiment (2006), only 10 to 20 successive freeze-thaw cycles are necessary to develop macro-cracks in intact chalk blocks and break them apart. Robinson \& Jerwood's (1987b) laboratory experiment on intact chalk blocks also concluded that material loss occurred in a matter of 14 cycles. And it may well be that their laboratory and field observations were in fact driven by segregation ice formation, but this theory spread out of periglacial processes studies more recently. Detailed sample observations to spot ice lenses were not specifically conducted.

In detail, Robinson and Jerwood (1987a) simulated tidal conditions on ten (7.6-cm $)^{3}$ intact chalk cubes collected in Upper Beeding quarry and replicated credible tidal conditions with sea water. Even though the laboratory rock was intact, unlike naturally-weathered platform chalk, these authors showed that spalls started occurring for temperatures below $-4.5^{\circ} \mathrm{C}$ for a minimum cycle duration of 4 continuous hours (cycles were tested by 2 hours increments), while no damage occurred with cycles lasting 2 hours. Temperature and exposure duration thus come out as two critical control parameters. Delunel et al. (2010) proposed, on the basis of segregation ice formation hypotheses, that rock damage estimates could be approached with a depth-integrated frost-cracking index (DFCl) as the total exposure duration below $-3^{\circ} \mathrm{C}$ and $-8^{\circ} \mathrm{C}$, assuming that there is no shortage of liquid water supply.

Finally, it appears that even under Western Europe's temperate coastal climates occasional cold winter conditions do occur occasionally and lead to noticeable chalk platform erosion. But converting controlled laboratory experiments to nature is not straightforward. The laboratory experiments highlight important parameters for frost shattering efficiency: lithology (Moses et al., 2006), platform location (Robinson and Jerwood, 1987a), temperature and exposure duration in a critical temperature bracket and salt water (Robinson and Jerwood, 1987a). 

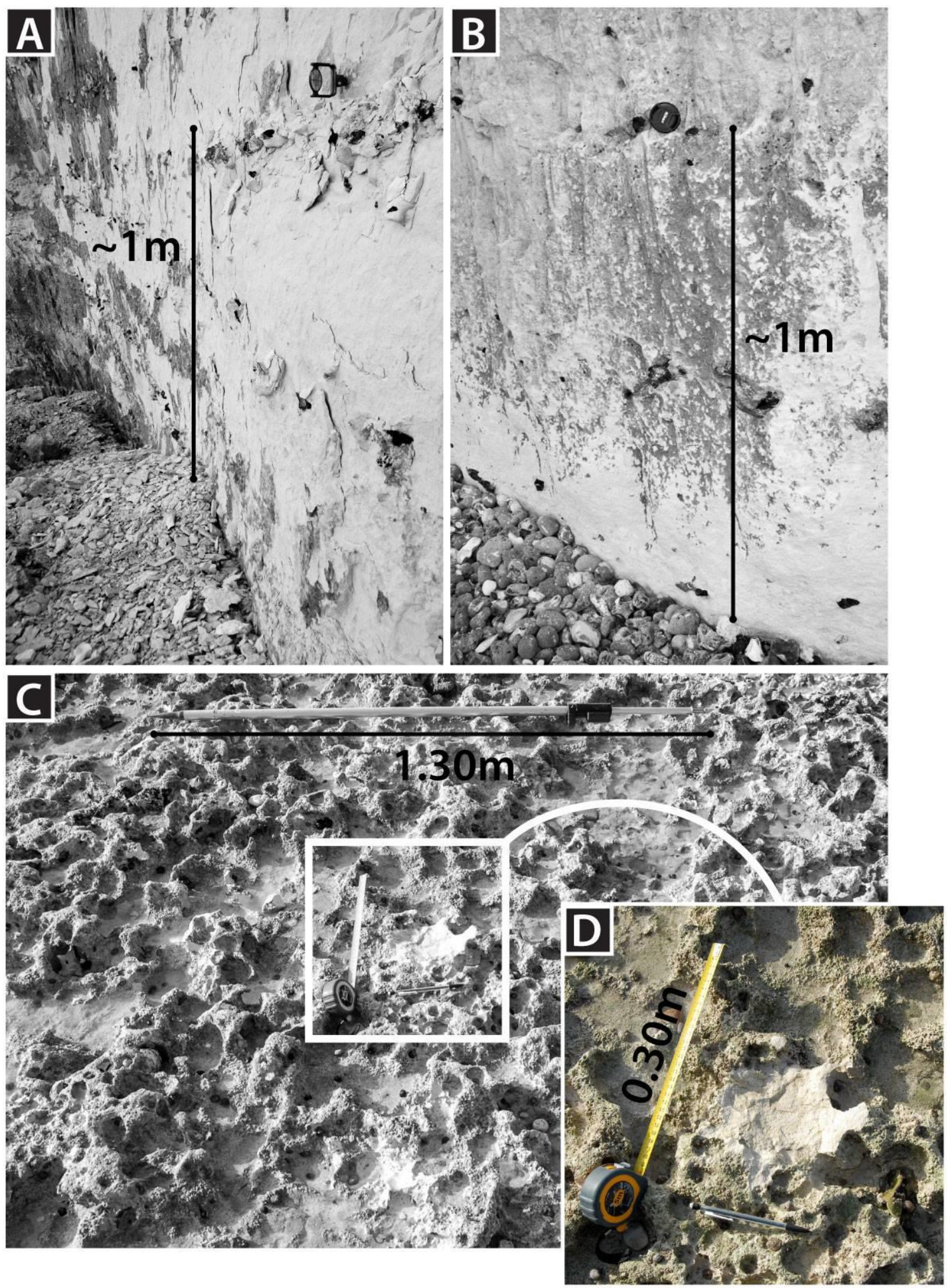

Figure 1. Example of frost spalling in chalk morphology. A and B: comparison of cliff foot when affected by frost shattering ( $A$, note the fallen flakes) and pebble blasting (B). $C$ and $D$ : effect on the shore platform. The white chalk flake detached in the pitted platform surface (C) is $\sim 17 \mathrm{~cm}$-long by 12-cm-wide by $3-\mathrm{cm}$-thick. The close-up photo (D) shows a local platform relief $3-5 \mathrm{~cm}$ high. Platform surface in this photo comes from a combination of nested by biological agents: $\mathrm{mm}$-scale holes by lithophagous worms (polydor), and 1-3-cm-scale holes by pholadidae (Zirfaea crispata). Note the brownish shiny presence of Actinia sp. in a hole close to the tape measurer's $10 \mathrm{~cm}$ mark. 
In this paper we conducted a field survey of rock spalling on the chalk platform at Mesnil Val
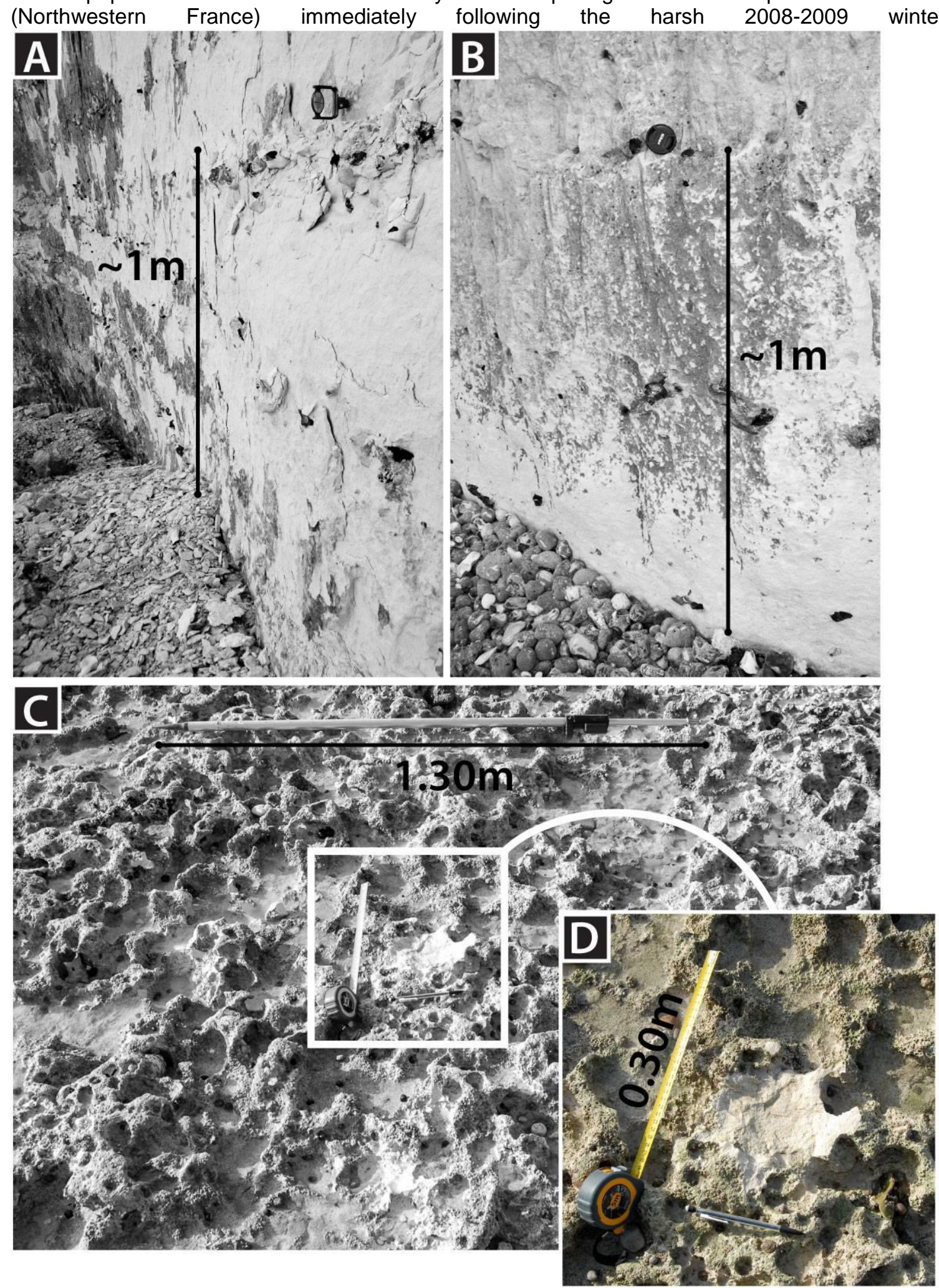

Figure 1), to quantify the contribution of frost shattering to platform erosion processes and relate it to elevation and lithological chalk facies and local morphology. 


\section{Study site (Mesnil Val) and methodology}

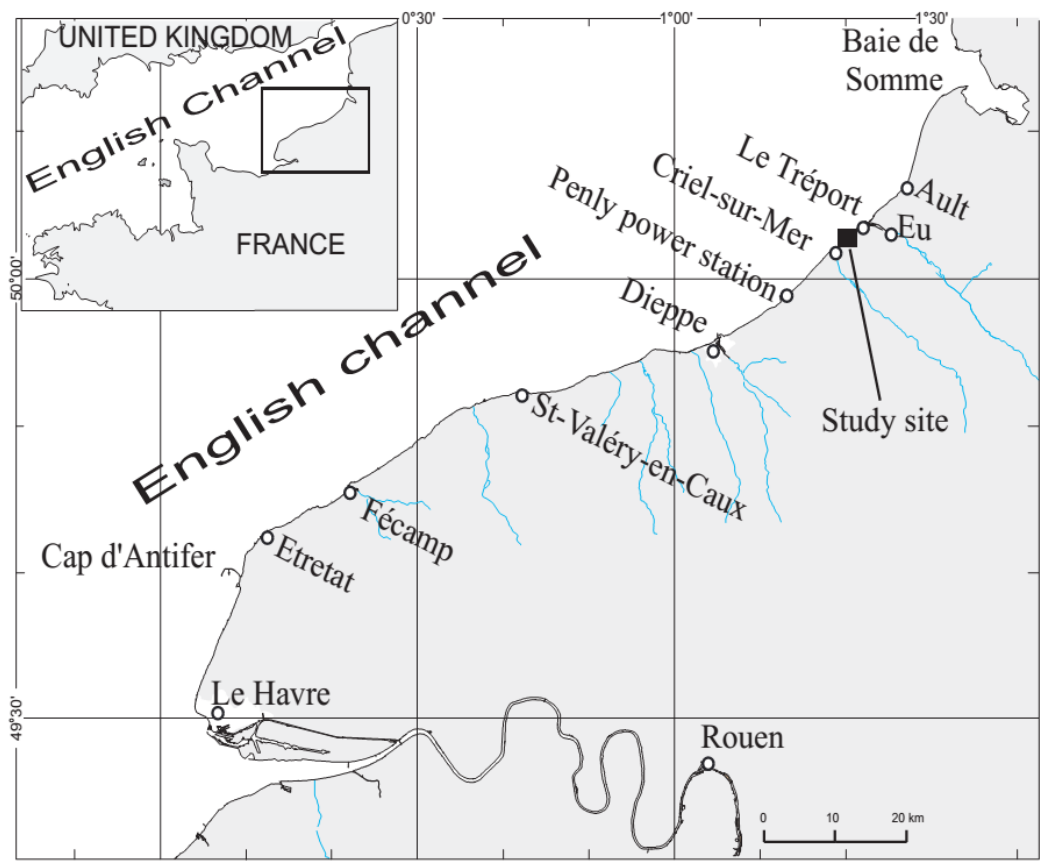

Figure 2. Study site location. Modified after Costa et al. (2005).

Mesnil Val is a chalk coastal site of Northern France, located along the English Channel between Le Tréport (NE) and Dieppe (SE) (Figure 2 and Figure 3). The chalk cliff height rises westward from $20 \mathrm{~m}$ in the dry valley to $80 \mathrm{~m}$ while the exposed shore platform at low tides extends from 200 to $600 \mathrm{~m}$ from the cliff toe. The average seaward slope of the platform is ca. $1 / 80\left(0.7^{\circ}\right)$ (Duperret et al., in press), but is higher $\left(1 / 40,1.4^{\circ}\right)$ where all the quadrats except Q16 and Q17 stand. Cliff retreat at Mesnil Val was quantified in three different ways: 30-years cliff head position comparison yields $15 \mathrm{~cm} / \mathrm{yr}$ (Costa et al., 2004), cliff retreat averaged over several millennia from ${ }^{10} \mathrm{Be}$ concentration profiles is calculated as 11$13 \mathrm{~cm} / \mathrm{yr}$ (Regard et al., 2012); while integration of terrestrial laser scanner surveys mapping erosion scar over 2.5 years comes as $18 \mathrm{~cm} / \mathrm{yr}$ (Dewez et al., 2013). Given these recession rates and assuming that Sunamura's cliff/platform recession model (Sunamura, 1992) holds true, the Mesnil-Val platform should lower at a rate of about 3-4 mm/yr, for a gradient of $1 / 40\left(1.4^{\circ}\right)$ and a cliff recession rate of 150 $\mathrm{mm} / \mathrm{yr}$. This lowering rate is higher than that cited in Regard et al. (2012) $(1 \mathrm{~mm} / \mathrm{yr})$. This is because Regard et al. (2012) deliberately chose a shallower platform transect (slope gradient of $1 / 150 ; 0.38^{\circ}$ ) to reach ${ }^{10} \mathrm{Be}$ sampling locations much further out to sea and access a more ancient cliff residence position. Here, quadrats were located along a steeper platform section, hence the stronger expected erosion rate. From a structural point of view, the cliff and platform chalk of Mesnil Val is sub-horizontally bedded, with a very shallow seaward dip. The cliff foot is at ca. $4.60 \mathrm{~m}$ (above NGF69 datum or $10.05 \mathrm{~m}$ above SHOM's hydrographic datum), while the lowest visible part of the platform, at the lowest tides lies at around $3.20 \mathrm{~m}$ (NGF69; $1.25 \mathrm{~m}$ above SHOM datum). Because of hardened chalk horizons called hard-grounds (see next paragraph), the platform exhibits a small relief resembling mesa monoclines structural landscape with bed edges of the order of 40-50-centimeters creating steps. The horizontal retreat of these steps was quantified by Regard et al. (2013) at $\sim 2 \mathrm{~cm} / \mathrm{yr}(\sim 10 \%$ of the cliff retreat rate). This horizontal retreat rate translates into vertical lowering $0.32 \pm 0.008 \mathrm{~mm} / \mathrm{yr}$. This is about one third of the total platform lowering assuming Sunamura (1992)'s slope parallel platform erosion model.

\section{a. Chalk Lithology and Porosity}

At Mesnil-val, the Upper-Cretaceous chalk belongs to the Lewes Nodular Chalk Formation, straddling Upper Turonian and Lower Coniacian ages (Mortimore et al., 2001). Lithologicaly, the Lewes Nodular Chalk is a yellowish coarse chalk with nodules, that contains soft, marly bands and nodular hardgrounds, with regular flint layers (Bristow et al., 1997; Mortimore and Pomerol, 1987). 


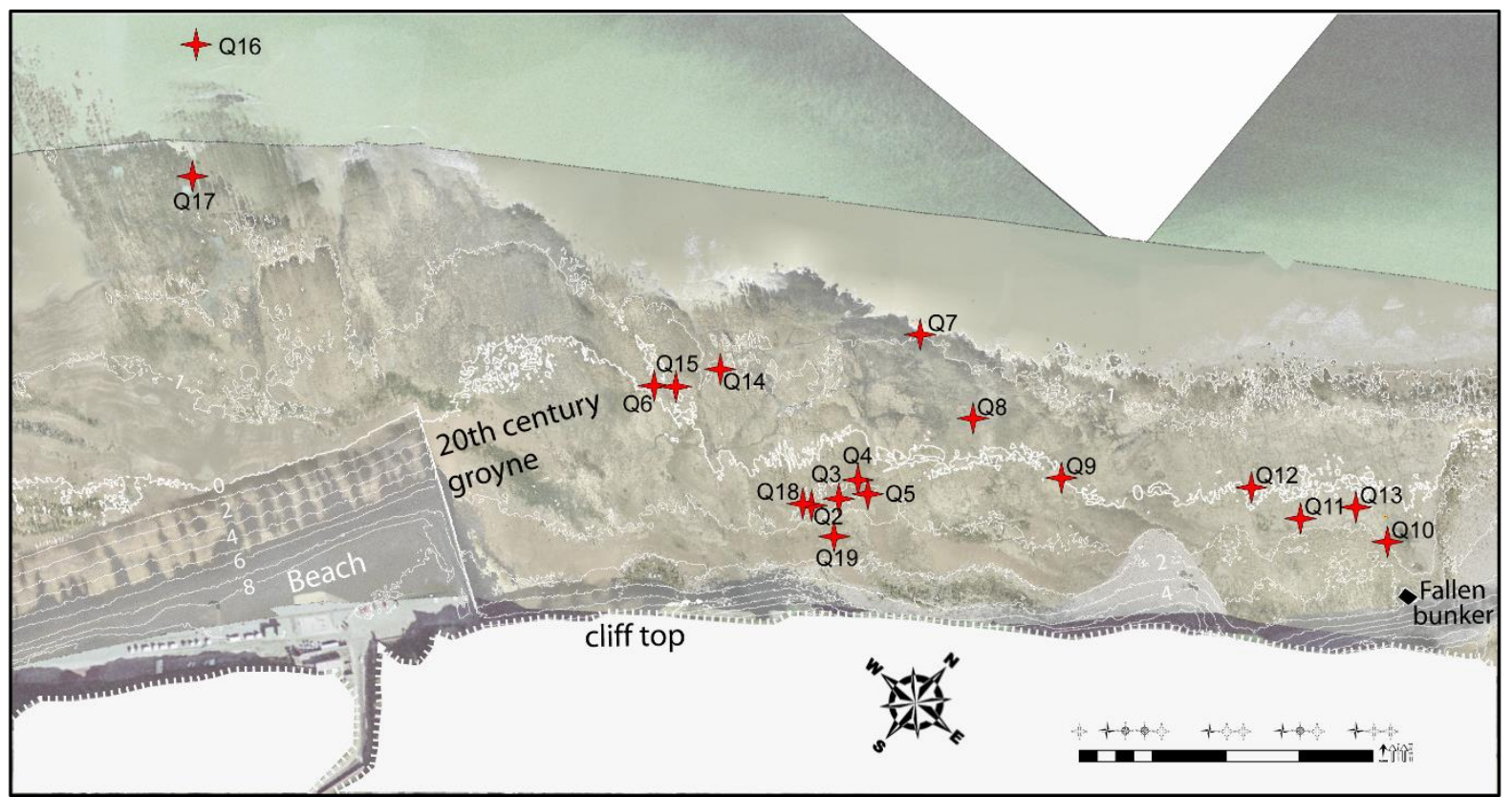

Figure 3. Map of Mesnil-Val platform (see figure 2 for location). The cliff is facing NW. White lines are 1-m-contours derived from helicopter-borne lidar survey of 13 March 2009; the bold contour is the $0 \mathrm{~m}$ level relative to NGF69 datum. Stars mark quadrat locations. The photograph was taken at rising tide. Tide can be lower, allowing for measurements farther, like in Q16 for example.

At Mesnil-Val, specific stratigraphic description identified sub-horizontal beds of Upper Turonian Chalk exposed in the shore platform and cliff base, with the occurrence of the Mers Hardgrounds, a condensed and hard section of Lewes Nodular Chalk which corresponds to the Kingston Beds in the UK stratigraphy (Mortimore et al., 2001). Many of the marls and flints at this level coalesce due to the condensed nature of this section but the Bo-Peep Flint Band, Lewes Nodular Flint Band, Lewes Marl and the overlying associated Criel Flint Band are all recognisable in the lower part of the cliff (Senfaute et al., 2009). On the shore platform, various hardgrounds (HG), firmgrounds (FG) and flint bands are exposed. They formed during Middle Turonian (Figure 4). The lower three hardgrounds (HGX, HGY, HGZ) correspond to the Glynde beds marking the base of the Lewes Nodular Chalk Formation. The Glynde beds delineate a seaward platform edge of about 2-3m high, mainly occurring between Low Neap Tide and Low Spring Tide elevations. Chalk rocks porosities determined on the Lewes Chalk Formation in France evidence porosities varying between 33 and $41 \%$, on "pure" chalky part sampled on the coastal cliff at Eletot (about 60km from Mesnil-Val) and in a borehole at Bois de Cise (about 8km northeast from Mesnil-Val), respectively (Duperret et al., 2005). The hardground succession observed on the shore platform appears to belong to Glynde beds and marl described in Sussex (UK), characterized by low porosities varying from 10 to $29 \%$ (Mortimore et al., 2001).

\section{a. Morphology of frost brecciation scars}

This paper is focused on the fact that chalk scars observed on the coastal platform in April 2009 can truly be assigned to frost brecciation. We believe they are for the following reasons. First, chalk rocks appear to be very sensitive to frost action (Lautridou and Ozouf, 1982). Isle of Thanet (UK) chalk strata provide evidence for frost brecciation during the last glacial period when they were covered by permafrost (Murton, 1996). Then, Mesnil Val site was regularly visited for terrestrial laser scanner surveys between December 2005 and April 2008, twice a year, before and after the winter (Dewez et al., 2013, 2007). On the cliff face, we observed that one specific bed was most prone to frost shattering. It is a 3-5m-thick chalk bed holding a perched water table above the impermeable Lewes Marl. Closeup cliff photographs shot in March 2006 show chalk flakes detaching from the cliff (Figure 1). Given that there had been thirteen individual spells of negative temperatures between December 2005 and March 2006, and that the observed damage occurred well above wave reach (Figure $1 \mathrm{~A}$ ), assigning scars to frost shattering is credible. When fresh scars are observed in this specific chalk bed, we assume that frost morphogenetic conditions are met on site. The reverse hypothesis was also tested and validated. During the summer period, when frost is absent, no flaking occurs on the cliff face. 


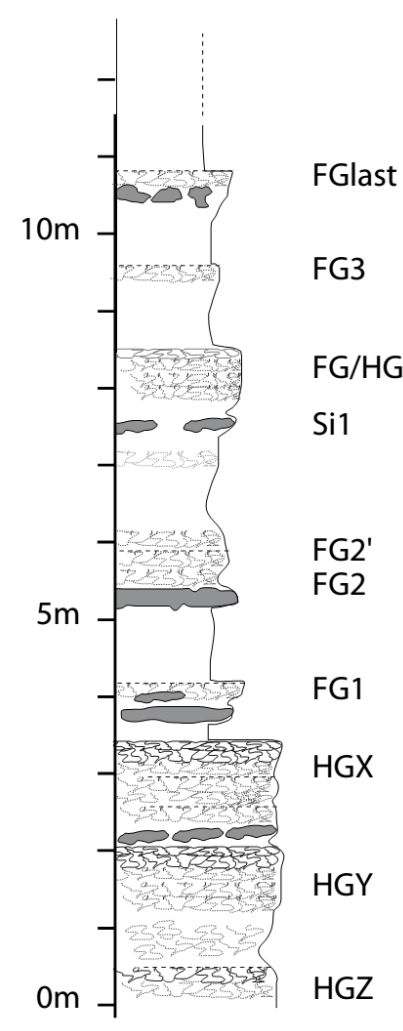

Figure 4. Stratigraphic column for Mesnil Val's shore platform. FG: firmground; HG: hardground. Height in column reflects the thickness of the layer, not the elevation (the layering is not horizontal).

In March 2009, when damage flakes were observed on the platform, field photos of the cliffs displayed the same frost damage features, when temperature records show that a severe frost snap occurred (Figure 5). There is therefore a strong temporal link between cliff damage and frost.

One may argue that the scars observed on the platform could merely be detached by pebble abrasion. Pebble abrasion scars however have smooth edges (Figure 1B, 1C and 1D), are much smaller in size (a few millimeters of diameter) and can only occur in the first 40-m from the cliff toe as shown on this site by Regard et al. (2013). The closest spot where systematic inventory of brecciation scars was performed (Q19) lies 54m from the cliff foot, well outside the range of pebble action. Brecciation may have occurred closer to the cliff but we did not investigate these areas due to safety concerns related to cliff collapse.

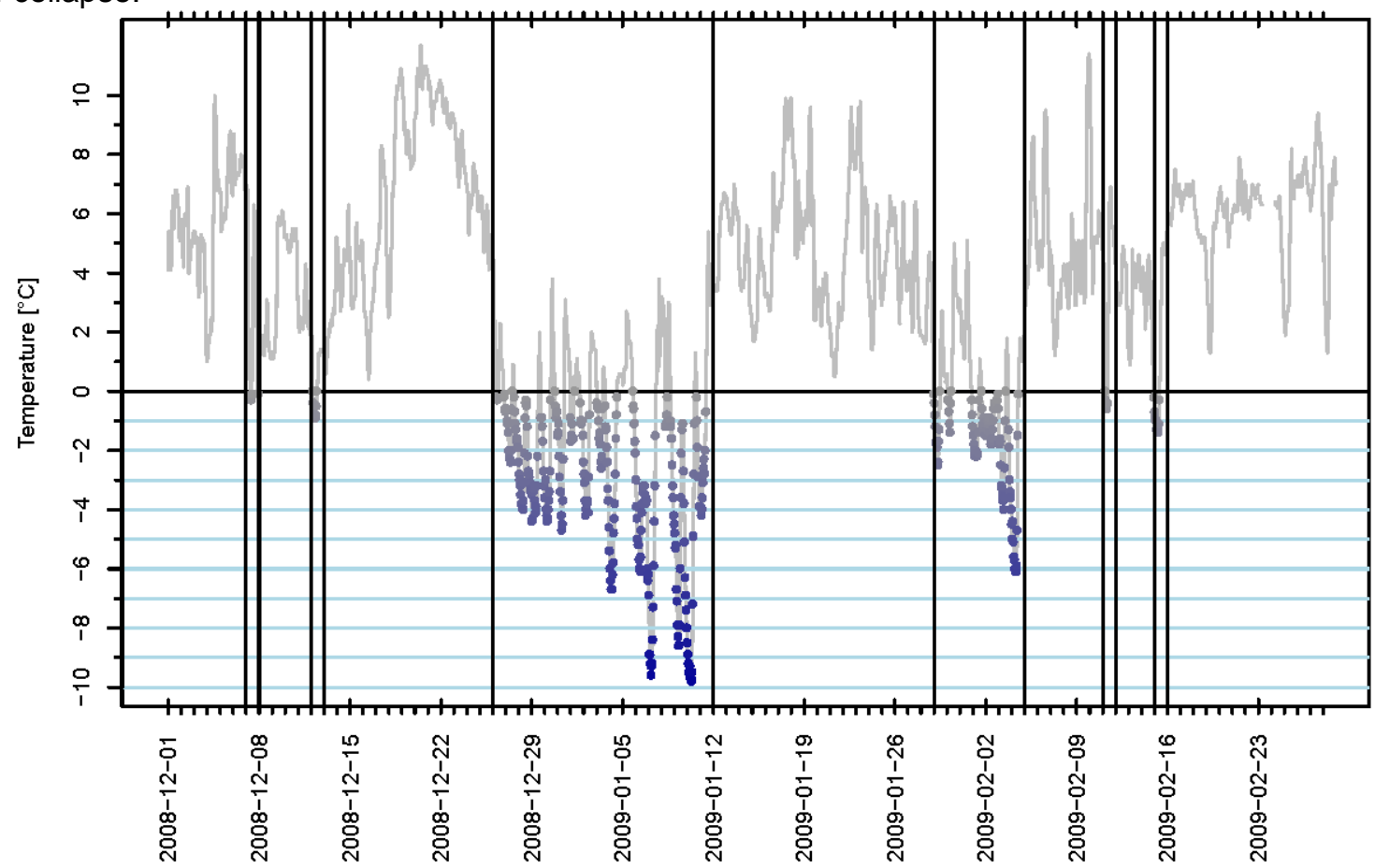


Figure 5. Minimum hourly air temperature series from MeteoFrance Dieppe weather station located $21 \mathrm{~km}$ west of Mesnil Val. Dots mark the occurrence of negative temperatures. Vertical lines delimit periods of frost. Apart from four, one-day, frost period, a longer sixteen-days-long period occurred between December 26 and January 12, and a eight-days period between January 29 and February 5.

Table 1. Quadrat characteristics and frost erosion.

\begin{tabular}{|c|c|c|c|c|c|c|c|c|c|c|c|c|c|}
\hline & $\begin{array}{l}\text { Area } \\
(\mathrm{m} 2)\end{array}$ & $\begin{array}{c}\text { Elev. } \\
(\mathrm{m})\end{array}$ & $\begin{array}{l}\text { Lithol } \\
\text { ogy* }\end{array}$ & Localisation & $\begin{array}{l}\text { Local } \\
\text { Relief } \\
\text { (cm) }\end{array}$ & $\begin{array}{c}\text { Relief } \\
\text { wavelength } \\
\text { (cm) }\end{array}$ & $\begin{array}{c}\text { scar } \\
\text { number }\end{array}$ & $\begin{array}{c}\text { Eroded } \\
\text { Volume } \\
\text { (cm3) }\end{array}$ & \pm & $\begin{array}{c}\text { Average } \\
\text { erosion } \\
(\mathrm{mm})\end{array}$ & \pm & $\begin{array}{c}\mathrm{Nb} \\
\text { cycles } \\
\text { below } \\
-2.5^{\circ} \mathrm{C}\end{array}$ & $\begin{array}{c}\text { Total } \\
\text { time } \\
\text { below } \\
-2.5^{\circ} \mathrm{C} \\
\end{array}$ \\
\hline Q02 & 2.18 & 1.08 & Fg1 & Planar surface & 10 & 20 & 58 & 2692 & 1437 & 1.24 & 0.66 & 25 & $102 \mathrm{~h} 00$ \\
\hline Q03 & 2.20 & 1.17 & Fg1 & Planar surface & 20 & 20 & 20 & 1479 & 768 & 0.67 & 0.35 & 25 & $103 \mathrm{~h} 20$ \\
\hline Q04 & 2.27 & 0.74 & $\mathrm{Fg} 1$ & Edge & 5 & 10 & 77 & 3627 & 1932 & 1.60 & 0.85 & 25 & $96 \mathrm{~h} 00$ \\
\hline Q05 & 2.17 & 1.06 & $\mathrm{Fg} 1$ & Edge & 5 & 10 & 93 & 1126 & 700 & 0.52 & 0.32 & 25 & $101 \mathrm{~h} 50$ \\
\hline Q06 & 2.29 & 0.01 & $\mathrm{Fg} 1$ & Planar surface & 5 & 50 & 15 & 11663 & 5872 & 5.09 & 2.56 & 24 & $83 \mathrm{~h} 50$ \\
\hline Q07 & 2.51 & -1.25 & Hgy & Planar surface & 15 & 20 & 36 & 870 & 511 & 0.35 & 0.20 & 21 & $55 \mathrm{~h} 10$ \\
\hline Q08 & 2.31 & -0.26 & $\mathrm{Hgx}$ & Planar surface & 5 & 30 & 19 & 516 & 288 & 0.22 & 0.12 & 24 & $78 \mathrm{~h} 10$ \\
\hline Q09 & 2.30 & 0.11 & $\mathrm{Hgx}$ & Planar surface & 5 & 30 & 36 & 368 & 230 & 0.16 & 0.10 & 24 & $84 \mathrm{~h} 10$ \\
\hline Q10 & 2.25 & 0.78 & $\mathrm{Hgz}$ & Planar surface & 5 & 15 & 35 & 661 & 382 & 0.29 & 0.17 & 25 & $96 h 10$ \\
\hline Q11 & 2.26 & 0.58 & $\mathrm{Hgz}$ & Planar surface & 20 & 40 & 15 & 3296 & 1697 & 1.46 & 0.75 & 25 & $93 \mathrm{~h} 40$ \\
\hline Q12 & $2.25 \dagger$ & 0.00 & $\mathrm{Hgz}$ & Planar surface & 20 & 80 & 22 & 1948 & 1033 & 0.87 & 0.46 & 24 & $83 \mathrm{~h} 50$ \\
\hline Q13 & $2.25 \dagger$ & 0.27 & $\mathrm{Hgz}$ & Planar surface & 5 & 40 & 4 & 37 & 23 & 0.02 & 0.01 & 24 & $87 \mathrm{~h} 40$ \\
\hline Q14 & 2.46 & -0.77 & Fg1 & Planar surface & 5 & 80 & 16 & 269 & 153 & 0.11 & 0.06 & 23 & $66 \mathrm{~h} 10$ \\
\hline Q15 & 2.25 & 0.02 & $\mathrm{Fg} 1$ & Planar surface & 20 & 200 & 31 & 2951 & 1519 & 1.31 & 0.67 & 24 & $83 \mathrm{~h} 60$ \\
\hline Q16 & 2.38 & -1.70 & $\mathrm{Hgz}$ & Planar surface & 5 & 7 & 20 & 192 & 115 & 0.08 & 0.05 & 20 & $41 \mathrm{~h} 50$ \\
\hline Q17 & 2.31 & -1.17 & Fg1 & Edge & & & 47 & 220 & 170 & 0.10 & 0.07 & 21 & $56 \mathrm{~h} 20$ \\
\hline Q18 & 2.15 & 1.13 & Fg1 & Planar surface & 4 & 10 & 18 & 203 & 124 & 0.09 & 0.06 & 25 & $102 \mathrm{~h} 10$ \\
\hline Q19 & 2.32 & 1.53 & Fg1 & Planar surface & 4 & 10 & 103 & 1070 & 651 & 0.46 & 0.28 & 25 & $109 \mathrm{~h} 20$ \\
\hline \multicolumn{2}{|c|}{ Average } & & & & & & & 1844 & 1253 & 0.81 & 0.55 & & \\
\hline
\end{tabular}

${ }^{*}$ cf stratigraphic log (4)

† estimation

\section{b. Spalling data collection}

Frost spalling data were collected in the second week of March 2009, well after the last frost snap of the winter. The inventory thus contains the total effect of the 2008-2009 winter frost. A stratified sampling scheme was applied to collect the data inside $\sim 1.5 \times 1.5 \mathrm{~m}^{2}$ quadrats (Erreur ! Source du renvoi introuvable., Figure 2 and Figure 6). The sampling design aimed to isolate chalk lithological facies behaviour, local morphology (i.e. plateau vs micro-cliff edges position) and platform elevations (surrogate for exposure time). For any combination category, quadrats locations were picked at random without seeking specifically damaged areas. The quadrat corners were marked with survey pins (Figure 6 ) pitched in the platform and surveyed with an EDM-Total station (XYZ location uncertainty is better than $5 \mathrm{~cm}$ ) and tied to NGF69 datum through DGPS-surveyed pins.

The number of rock scars were counted, their long- and short-axis measured and their height estimated relative to the local neighboring relief. It is assumed that each scar is an elementary rectangle while volume computation assumes a rectangular prism shape. Given that true prismatic shape is unlikely in nature (see for example Figure 6), we assume a volume uncertainty of $50 \%$, except for dimensions less than $1 \mathrm{~cm}$ for which the uncertainty is $0.5 \mathrm{~cm}$ (Erreur ! Source du renvoi introuvable.). 


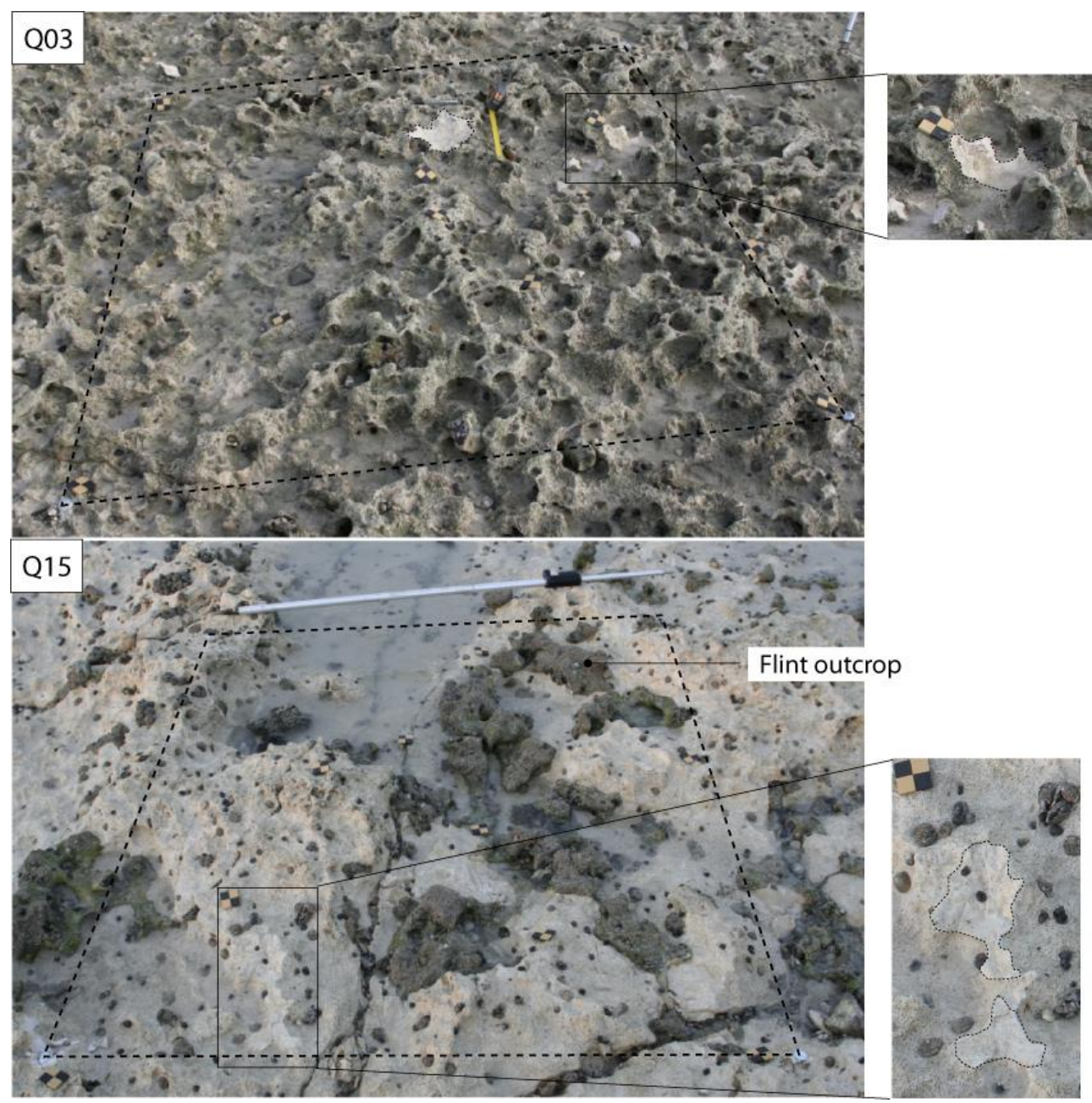

Figure 6. Exemple of quadrats: Q03 and Q15; right: zoom on a specific scar, clearly visible. Discontinuous line is the quadrat boundary. Both quadrats show different micromorphologies controlled by bio-erosion.

\section{c. Temperature record}

The reference temperature series used in this paper are hourly minimal air temperature of Dieppe's MeteoFrance station, $21 \mathrm{~km}$ west of the field site between 12/01/2008 and 02/28/2009 (Figure 5 and Figure 7). We acknowledge that estimating ground temperature from a remote air temperature weather station record would ideally require site specific transfer functions with additional parameters such as humidity and ground vs air temperature for correct estimates. None of this was available and quantitative results presented should be examined with this limitation in mind. Ground temperatures could be 0 to $5^{\circ} \mathrm{C}$ below air temperatures at the standard $1.5 \mathrm{~m}$ elevation of a Stephenson's Screen (cf. Robinson and Jerwood, 1987a). Nevertheless, in an attempt to check for spatial correlation between Dieppe and 


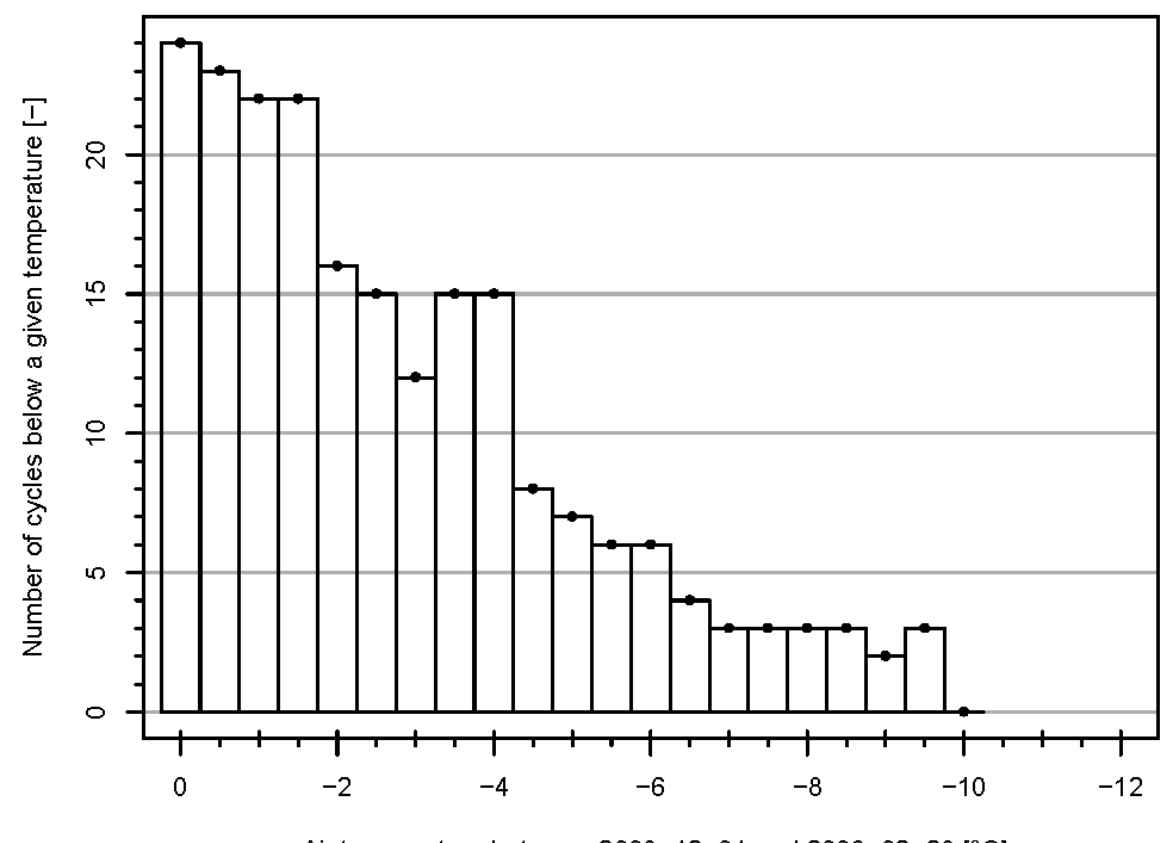

Air temperature between $2008-12-01$ and $2009-02-28\left[{ }^{\circ} \mathrm{C}\right]$

Figure 7. Number of frost cycles recorded by minimum hourly air temperature below a given temperature threshold, during the winter 2008-2009 at Dieppe MeteoFrance weather station. This presents the absolute exposure to freezing temperature during the winter. All these cycles affected the cliff face, but not all of them concerned the platform due to tide cycles and subsequent shielding by sea water.
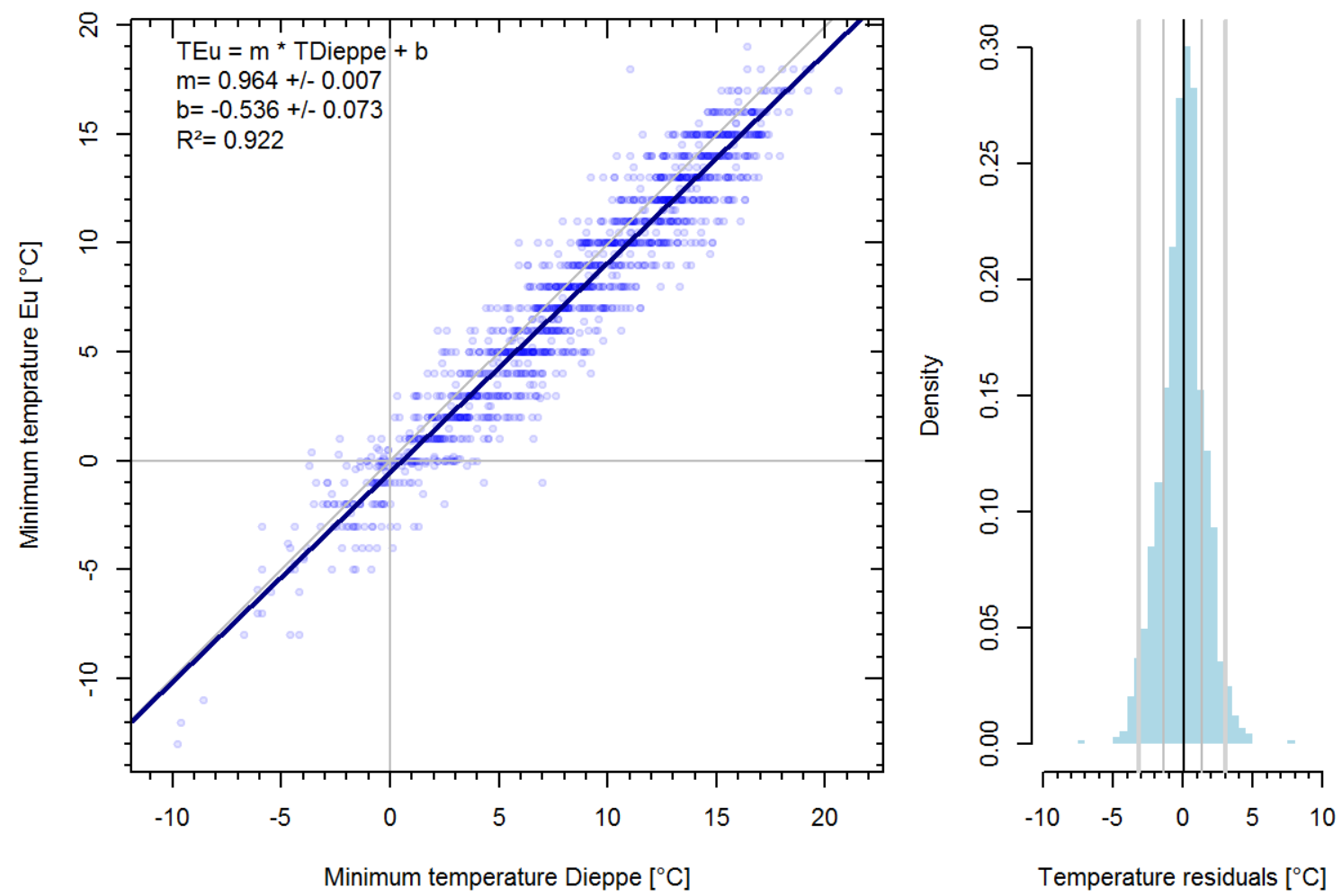

Figure 8. Comparison of minimum air temperatures at Dieppe and Eu Meteofrance stations (MesnilVal is located in between, Figure 2; Eu is $3.5 \mathrm{~km}$ east from the coast). The blue line is the linear model predicting Eu minimum temperature from Dieppe minimum temperature. The residuals are indicated in the right panel: The Dieppe temperatures minimum daily temperatures explain $92 \%$ of the variability and predict Eu temperatures within $+/-1.3^{\circ} \mathrm{C}$ (at 1-sigma confidence level).

Mesnil Val, a temperature correlation plot is presented in Figure 8. This plot shows that minimum air temperatures recorded at Meteofrance weather stations in Dieppe and Eu (3.5km east from the coastal site), and it is apparent that the average minimum daily temperature is cooler by $0.5^{\circ} \mathrm{C}$ in Eu than in Dieppe. Temperatures rise slower in Eu than in Dieppe but only by $0.04^{\circ} \mathrm{C}$ per unit. The Dieppe 
temperatures minimum daily temperatures explain $92 \%$ of the variability and predict Eu temperatures within $+/-1.3^{\circ} \mathrm{C}$ (at 1-sigma confidence level, Figure 8). One should note that the prediction trend of freezing temperature suffers less offset than higher temperatures. All this to say that despite the 20-oddkilometers separating Dieppe from Mesnil Val, using Dieppe minimal air-temperature is reasonable, at least at the daily scale. On a hourly temperature basis, there might exist a phase shift, which cannot be tested for the lack of hourly record at Eu weather station. We will consider that in a first order, Dieppe temperatures are a good enough proxy.

\section{d. Tidal modulations}

The temperature felt by the platform was modulated by tides, with sea water remaining positive at all time, while air temperature fluctuated above and below freezing. Tides in the English Channel are semidiurnal with two tides per day. Water level fluctuations were simulated on a 10-minutes-basis using FES 2004 (Lyard et al., 2006) between 01 December 2008 and 30 March 2009. At high spring tide, the shore platform of Mesnil Val is entirely flooded and water level reaches the cliff toe (Figure 9). All the quadrats, as it turns out, were sampled between high- and low-neap-tide levels (Figure 9).

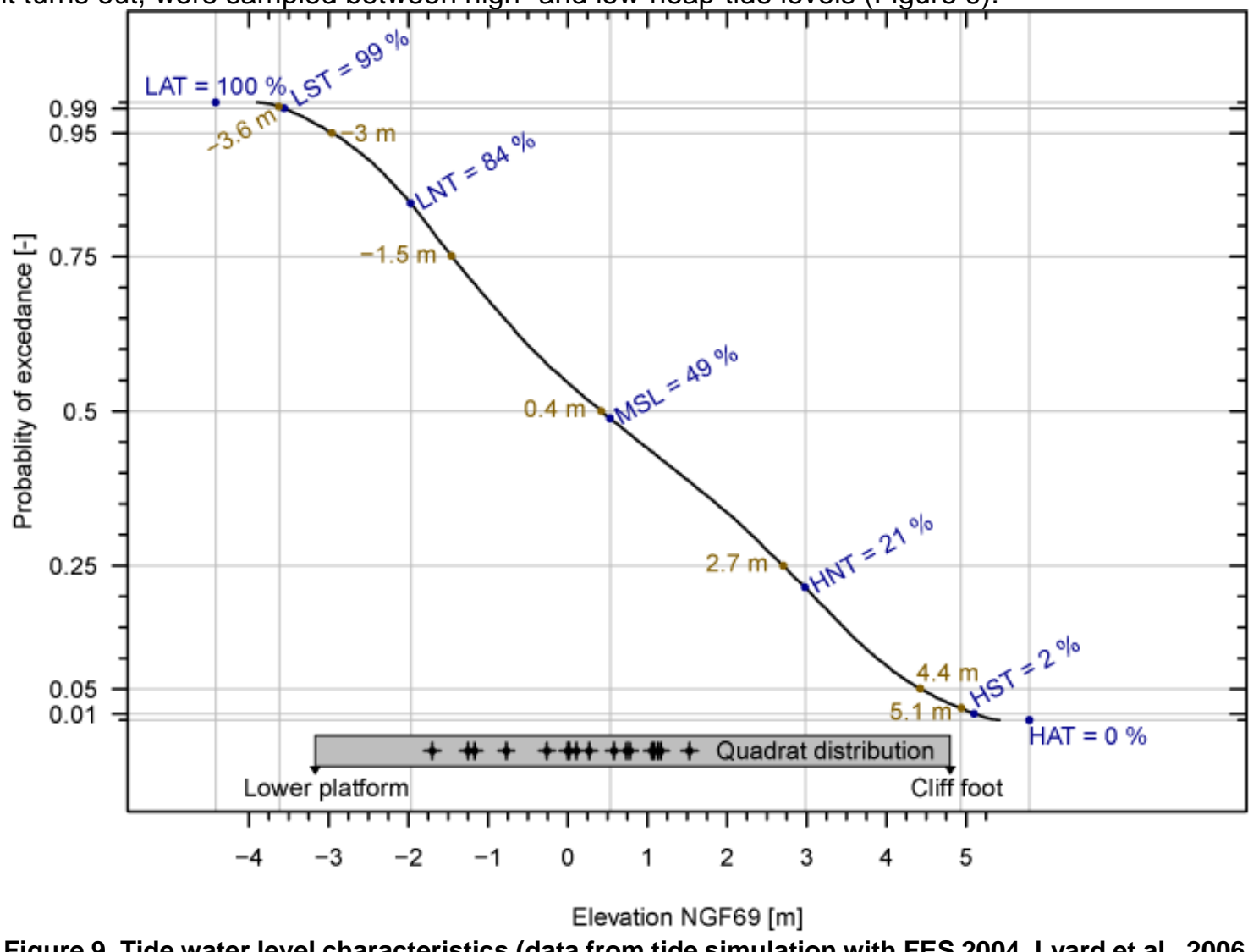

Figure 9. Tide water level characteristics (data from tide simulation with FES 2004, Lyard et al., 2006, between 01 December 2005 and 30 April 2009 at Mesnil Val). Brown elevations on the curve indicate tide elevation quantiles. Dark blue annotations describe characteristic water levels (from SHOM 2011). At the bottom, the grey rectangle shows the vertical extent of the shore platform. Crosses show sampled quadrat elevations. LAT: Lowest Astronomical Tide; LST: Low Spring Tide; LNT: Low Neap Tide; MSL: Mean Sea Level; HNT: High Neap Tide; HST: High Spring Tide; HAT: Highest Astronomical Tide).

\section{Results and discussion}

\section{a. Number and duration of frost episodes affecting the platform}

During the 2008-2009 winter, air temperature dropped below $0^{\circ} \mathrm{C}$ in six main episodes (7-8 Dec., 12-13 Dec., 26 Dec-12 Jan., 29 Jan.-05 Feb., 11-12 Feb. and 15-16 Feb, Figure 5), the longest lasted sixteen continuous days, and the second longest lasted eight-days, the others were just one or two days. During the longest period, at the hinge between 2008 and 2009, the temperature dropped down to $-9.5^{\circ} \mathrm{C}$ (Figure 5). In finer details (Figure 7), a count of freeze-thaw cycles counted 24 temperature drops below $0^{\circ} \mathrm{C}$, for a total duration of 180 hours (precisely 179 hours and 50 minutes). There were 15 cycles down 
to $-4.5^{\circ} \mathrm{C}$ (total duration 71 hours and 10 minutes) and even 3 drops down to $-9.5^{\circ} \mathrm{C}$ (total duration 5 hours 30 minutes).

\section{b. Observed erosion rates}

Even though the sites were picked at random, all the quadrats showed erosion, in the form of detached flakes of salient chalk with sharp and unrounded edges - hence from frost-damaged and not pebble impact. Depending on the quadrat, there were between 4 and 103 scars. Their individual surface ranges from $10^{-4}$ to $10^{-1} \mathrm{~m}^{2}$ (3 orders of magnitude) while their volumes ranges from $10^{-6}$ to $10^{-2} \mathrm{~m}^{3}$ (4 orders of magnitude). Quadrat total volumes divided by exact quadrat surfaces indicate lowering rates ranging from 0.02 and $2.00 \mathrm{~mm}$ (Erreur ! Source du renvoi introuvable. and Figure 10).

Quadrat Q6 stands out of this pool of observations with an exceptional $5 \mathrm{~mm}$ of lowering. On average, frost brecciation has removed a layer of $0.8 \pm 0.5 \mathrm{~mm}$ of chalk during the sole 2008-2009 winter (Figure 10). This is about $20-25 \%$ of the total downwearing expected in one year.

Spatially, erosion seems to change sharply at the 0m (NGF69, or $4.45 \mathrm{~m}$ in SHOM datum) elevation mark. Below this elevation, erosion is of the order of $0.2 \mathrm{~mm}$. Above this elevation, average lowering is much scattered. Such erosion regime change does not seem to be explained by chalk stratigraphy as both chalk facies $\mathrm{Fg} 1$ and $\mathrm{Hgz}$ occur above and below this elevation mark. A possible explanation may be related to minimal frost exposure time.

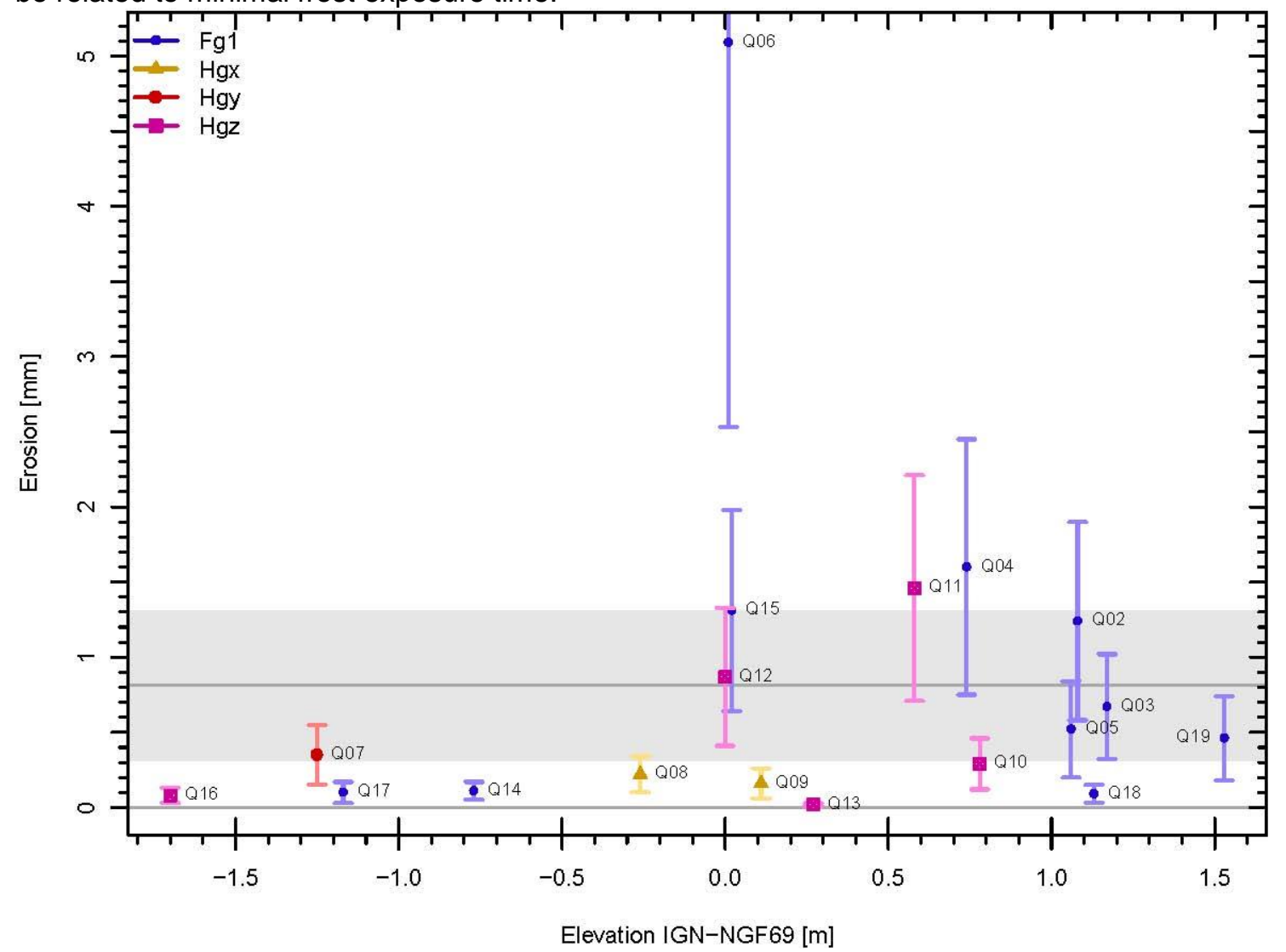

Figure 10. Platform frost shattering erosion as a function of quadrat elevation. Colours and symbol shapes represent chalk all four chalk types sampled (see Figure 4). The horizontal line depicts the average erosion at $0.8+/-0.5 \mathrm{~mm}$ error (light grey box).

\section{Dependence of erosion on frost duration}

Because laboratory experiments suggested that frost damage started occurring after $4 \mathrm{~h}$-long spells, Figure 11 synthesizes the durations of single emersion for each quadrat as a cumulated distribution. The cumulated duration is plotted against specific duration. This diagram shows that, very close to low neap tide level at -1.25m (NGF69), quadrat Q16 experiences very occasional 4-hours exposures, less than $5 \%$ of the time. This occurs despite being located below the seaweed level -below the level documented by Robinson \& Jerwood (1987a). On the contrary, at 1.5m (NGF69), quadrat Q19 is always exposed for periods longer than $7 \mathrm{~h}$ at a time at low tide. Thus if laboratory experiments are to be trusted, then all quadrats can experience frost damage conditions, though the lowest ones need a little bit of luck to feel short-lived temperature cycles. 

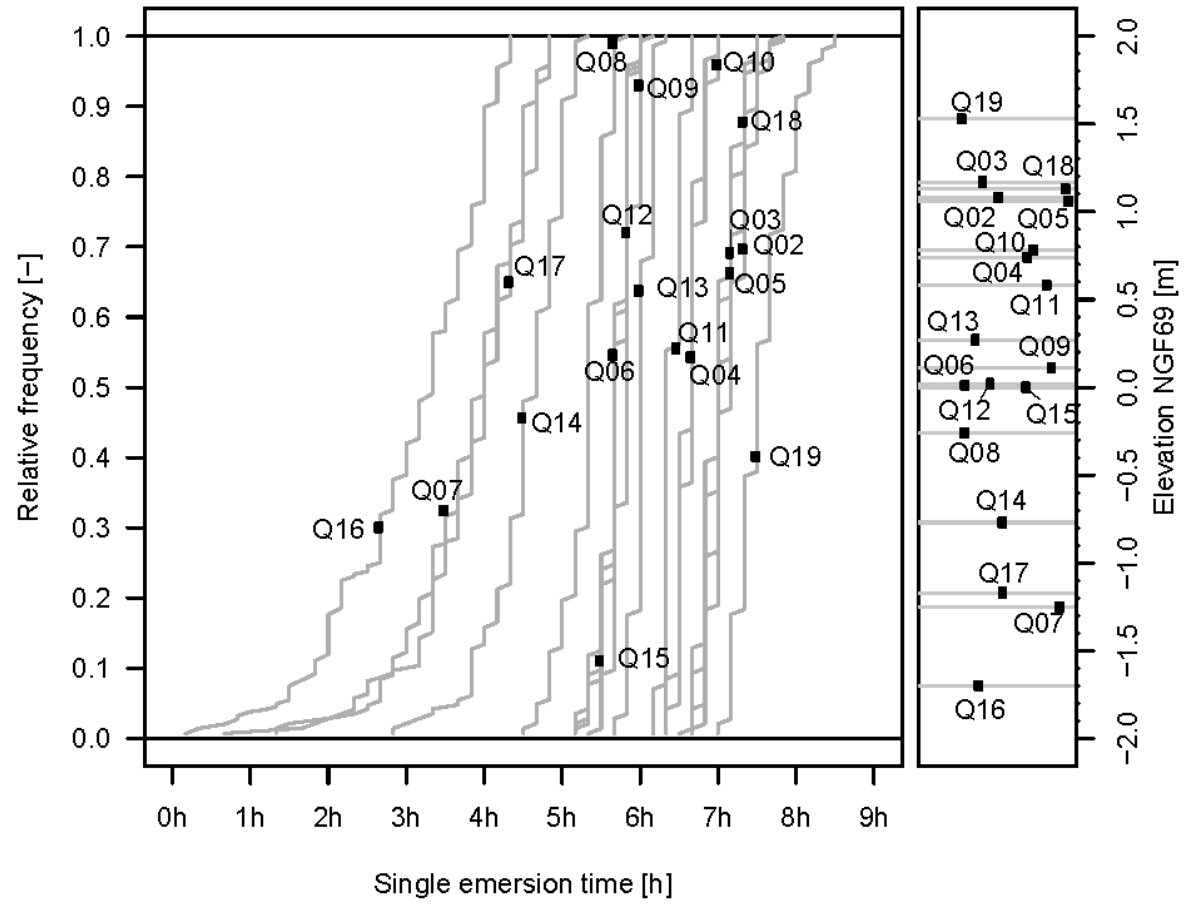

Figure 11. Left: Cumulated frequency of single emersion periods. Quadrat elevation is relative to NGF69 datum. The lowest quadrat (Q16) only comes half the time out of the water for continuous stretches of 3 hours, but can also be entirely covered during neap low tides. The highest quadrat (Q19) always comes out of the water for periods of 7 hours or longer. Right: quadrat elevation relative to NGF69 datum. Note that the solid square on the curves only mark the annotation anchors, they do not have any statistical meaning.

Delunel et al. (2010) suggested that total amount of time spent below a threshold temperature was a metric for quantifying frost damage intensity. We picked $-2.5^{\circ} \mathrm{C}$, the freezing temperature of sea water, and $-4.5^{\circ} \mathrm{C}$ as suggested by Robinson and Jerwood (1987a) to examine how total exposure time was related to average erosion (Figure 12). The relation is not linear. Erosion responds by a broad scatter to a narrow range of total exposure time. This suggests that total exposure time is not the main control for erosion variations.

Rather than linearly, erosion may respond by a step function to total frost exposure time. Figure 12 shows that total erosion is low for samples exposed for a short total duration but after 27 hours below $4.5^{\circ} \mathrm{C}$, or after 83 hours of exposure below $-2.5^{\circ} \mathrm{C}$, a sharp contrast in erosion becomes visible. This threshold-driven behavior suggests a link to the integer number of cycles spent below a given temperature, as shown in laboratory experiments (see below).

A range of exploratory tests were conducted with the integral freezing time. Lithological differences or site specific conditions such as differential moisture content, or more generically to different porosity values were tested. Another possible explanation may relate to a minimum fatigue conditions over which chalk would break more easily. The erosion rate was also computed by dividing quadrat average erosion by the time exposure under the limit value (cf. Figure 15). No linear relationship exists between elevation (or time exposure) and the erosion (or erosion rate) (Figure 12 and Figure 15). 


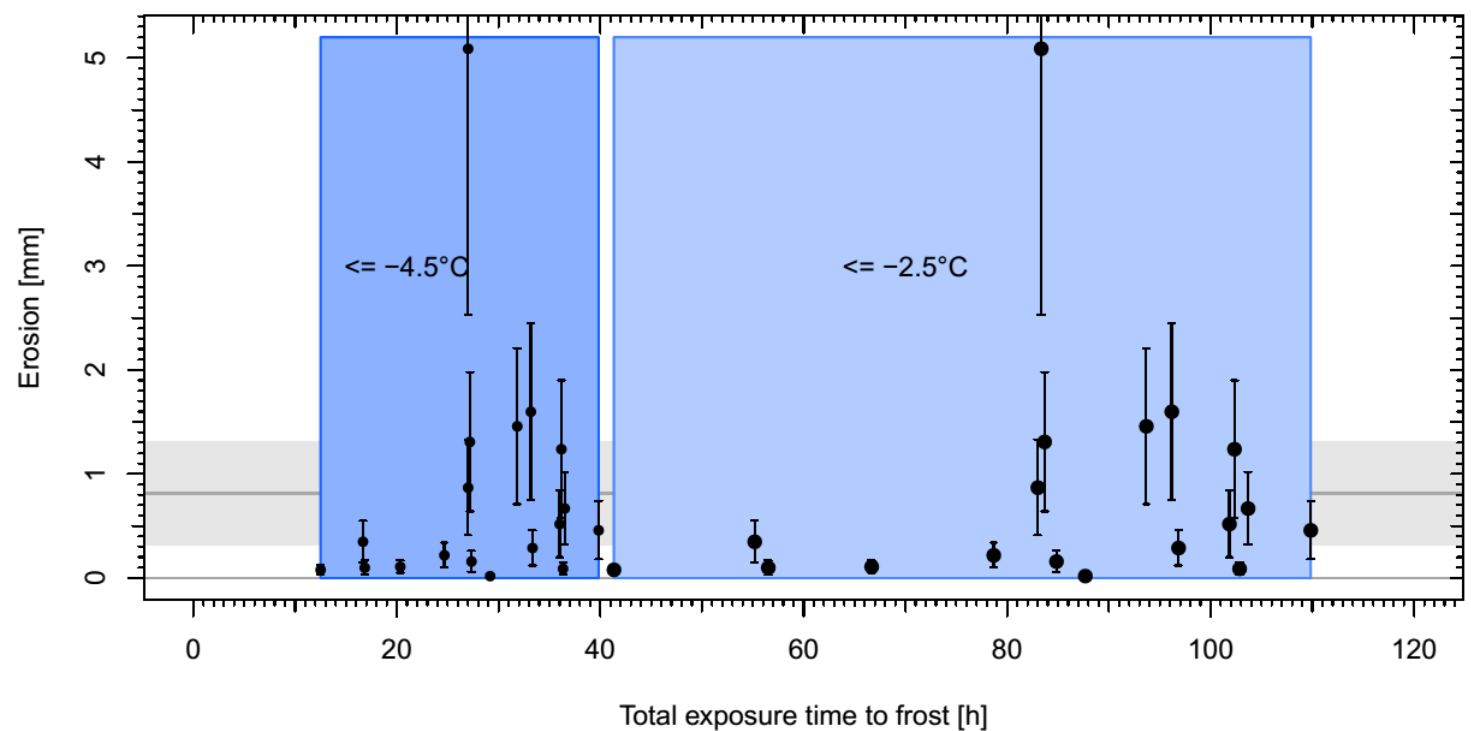

Figure 12. Erosion as function of total exposure time respectively below $-2.5^{\circ} \mathrm{C}$ and $-4.5^{\circ} \mathrm{C}$. Dot symbols reflect both temperature thresholds. The time spent below $-4.5^{\circ} \mathrm{C}$ varies much less for all quadrats than that spent below $-2.5^{\circ} \mathrm{C}$. This suggests that colder temperatures applied more evenly across the platform.

\section{d. Exposure of the platform to freezing conditions}

As discussed above, the stepped erosion response may respond to the number of sufficiently long frost cycles below a critical temperature. Figure 13 represents simultaneously the sequence and respective cycle durations below $-2.5^{\circ} \mathrm{C}$ of each quadrat (the graphs are sorted from lowest elevation (Q16) to highest elevation (Q19) and critical durations of 2 and 4 hours highlight efficient cycles).

On Figure 13, an interesting boundary condition appears. Quadrat Q16 suffered frost shattering $(0.08+/-$ $0.05 \mathrm{~mm}$ ) even though it was only exposed to 12 freezing cycles lasting longer than $2 \mathrm{hrs}$ but less than 3.5hrs. This means that just a dozen cycles for shorter durations than previously discussed in the literature could be effective morphogenetic conditions.

If the stepped behavior interpretation of Figure 12 applies, the complementary cumulative distributions (Figure 14) provide a vision of both the number and proportions of freeze-thaw cycles applied to the platform. If we assume that frost is only efficient when applied for more than $2 \mathrm{hrs}$ at a time, about a quarter of the freeze-thaw cycles are inefficient. If, like Robinson and Jerwood (1987a), we considered durations longer than $4 \mathrm{hrs}$ less than half freeze-thaw cycles could be deemed inefficient. This would imply that just about 10 freeze-thaw cycles below $-2.5^{\circ} \mathrm{C}$ could be responsible for the observed erosion. The weather conditions observed in this study may well occur more often than previously thought.

\section{e. Dependence on lithology}

Figure 15 represents erosion rates as function of chalk lithological facies (cf. Figure 4) relative to the duration of frost conditions. Macroscopic lithological descriptions do not seem to control the intensity of frost shattering: only a slight increase of erosion is found for weaker chalky firmground (Fg1) compared to harder chalky hardgrounds (Hgz, Hgx and Hgy). Nodular chalks and hardgrounds, such as the Lewes Nodular Chalk (units Fg1, Hgx, Hgy and Hgz) represent syndepositional hardening of a former seabed. Due to diagenetic cementations, hardgrounds and firmgrounds are thus assumed to present lower porosities than "pure" white chalks (Mortimore et al., 2001). At a microscopic level, Lautridou et al. (1983), Prick (1997) and Murton et al. (2001) showed that pore size and open porosity could explain macroscopic erosion response. Ignoring of this crucial piece of the puzzle at the time of field data collection, we did not gather samples to measure chalk porosity. Literature does not describe the properties of these specific chalk beds. So based on the sole macroscopic lithological description, frost does not seem to produce clear and distinct signature in either firmground or hardgrounds.

To assess the sensitivity of rock types to erosion processes, data presented by Moses et al. (2006) were reexamined. They computed rock type sensitivity to three shore platform erosion processes: wetting and drying, frost weathering and abrasion (Table 2). Different experimental laboratory conditions do not allow for process efficiency inter-comparison for a given rock type, but the relative rock sensitivity is revealed for each process. If chalk is thus considered as the standard, chalk is twice more sensitive to frost weathering than hard limestone and 13 times more sensitive than crystalline rocks (Table 2). Under wetting and drying conditions, hard limestone is 15 times more resistant, while crystalline rocks are 9 times more so. And to abrasion, chalk is 6 times more sensitive than crystalline rocks. 

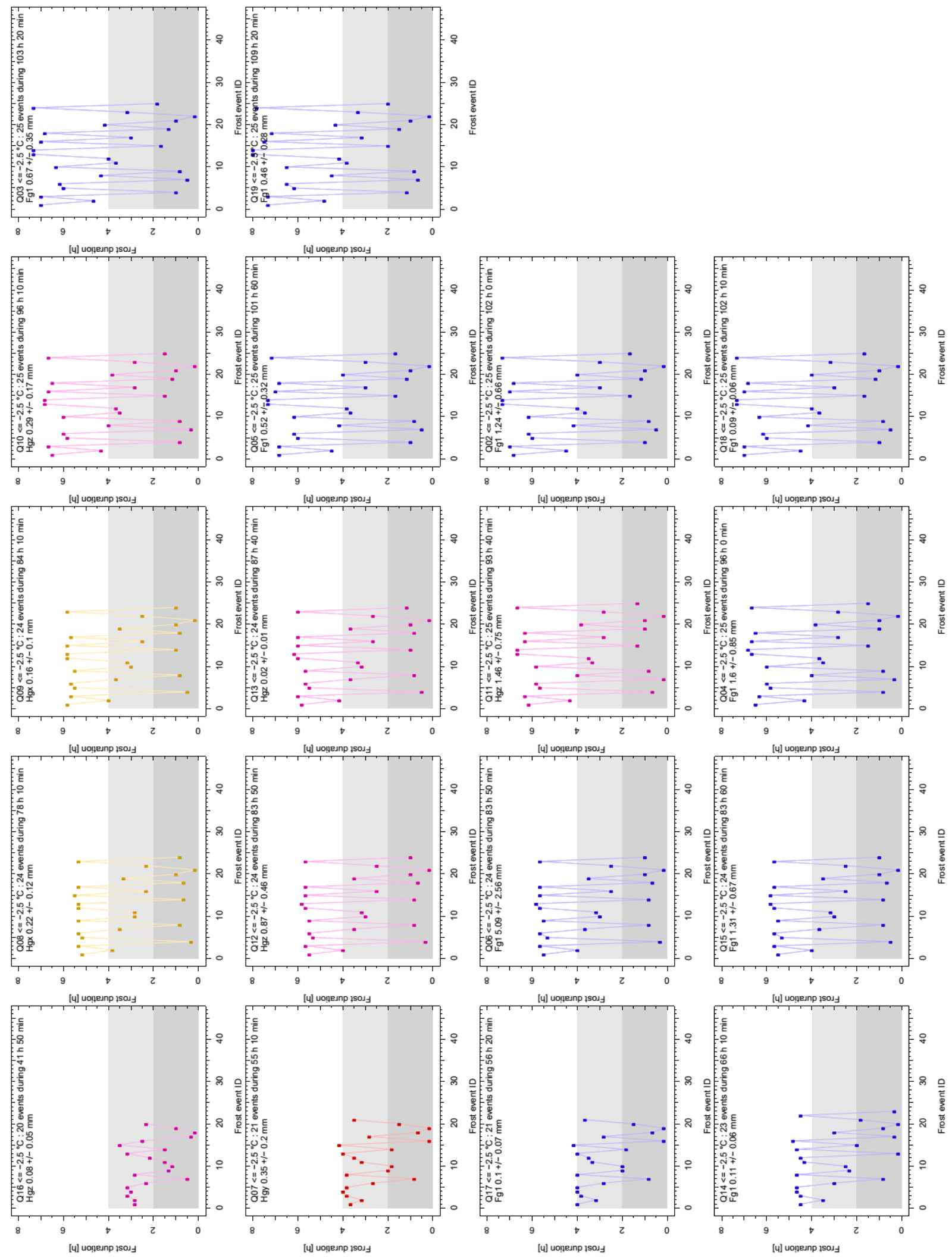

Figure 13. Quadrat exposure sequence to temperatures below $-2.5^{\circ} \mathrm{C}$. This diagram is complexe because we attempt to convey simultaneously elevation, total exposure time and number of exposure cycles below $-2.5^{\circ} \mathrm{C}$, the duration of each cycle below $-2.5 \mathrm{C}$ and erosion. Each graph represents the sequence of freeze-thaw cycles felt at each quadrat during the period 01 Decembre 2008 - 28 February 2009. The duration of each cycle is indicated as ordinate. Colours reflect the lithologies (Fg1, Hgx, Hgy, Hgz) with the same key as Figure 11. Graphs are sorted by column from the lowest elevation quadrat Q16 (top left) to the highest Q19 (right). Platform elevation clearly plays on the duration of single freeze-thaw exposures. The horizontal grey line figures the duration threshold of $4 \mathrm{~h}$, presumed to be the duration were damage starts occurring. 

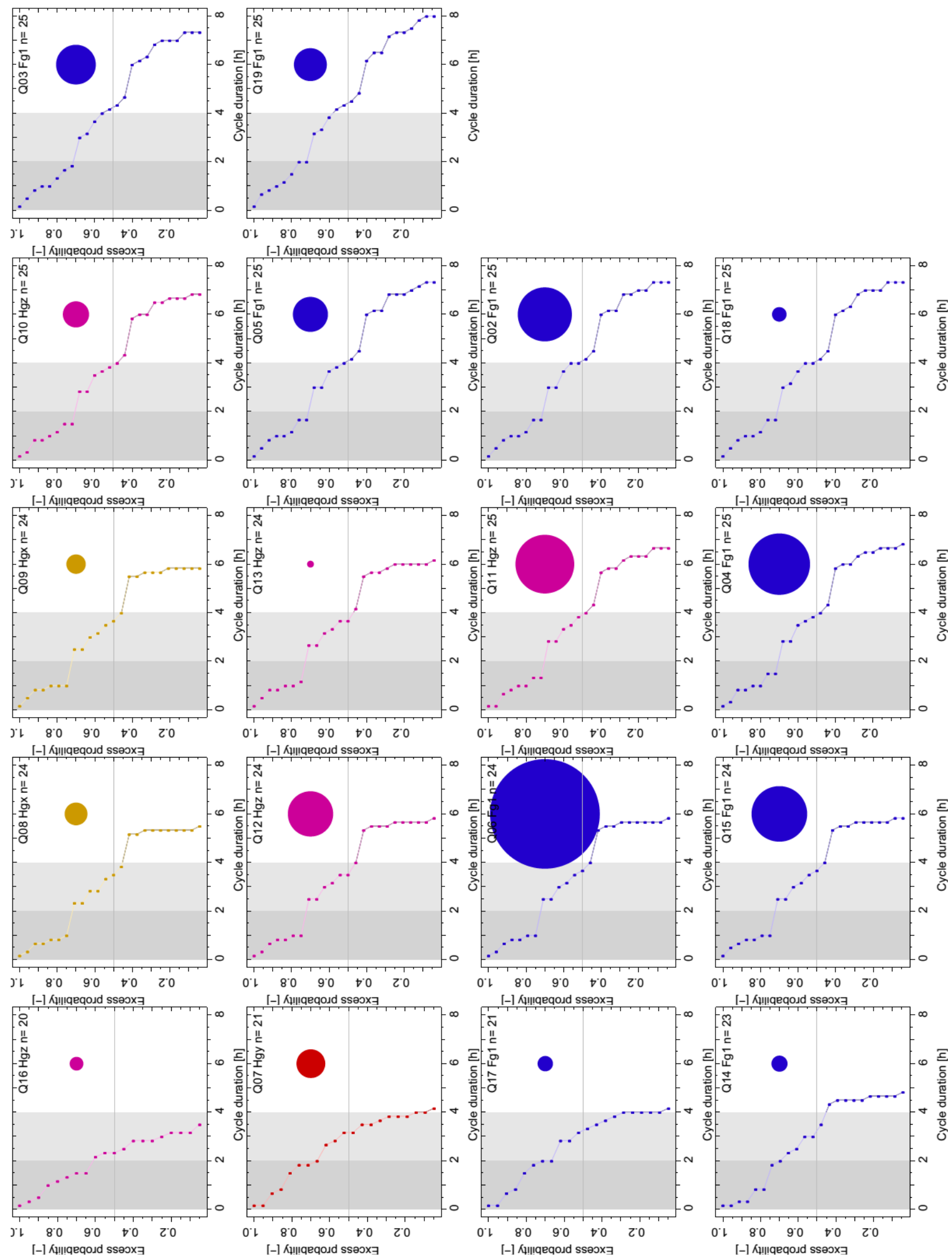

Figure 14. Distributions of durations for single freezing event below $-2.5^{\circ} \mathrm{C}$ per quadrat. Curves depict the probability of exceeding a given exposure time to temperatures below $-2.5^{\circ} \mathrm{C}$. Disks represent the amount of erosion (square root of values in Erreur! Source du renvoi introuvable.). Colours relate to chalk lithology (Hgz: pink; Hgy: red; Hgx: yellow; Fg1: blue). Grey shading figures critical durations of 2 hours and 4 hours.

In summary, this study emphasizes the importance of frost shattering as a morphogenic agent even under temperate climatic conditions like that of the English Channel chalk cliffs. According to Table 2, 
this conclusion may be transposed to other lithologies for which the ratio between wetting and drying, frost shattering and abrasion is of the same order of magnitude.

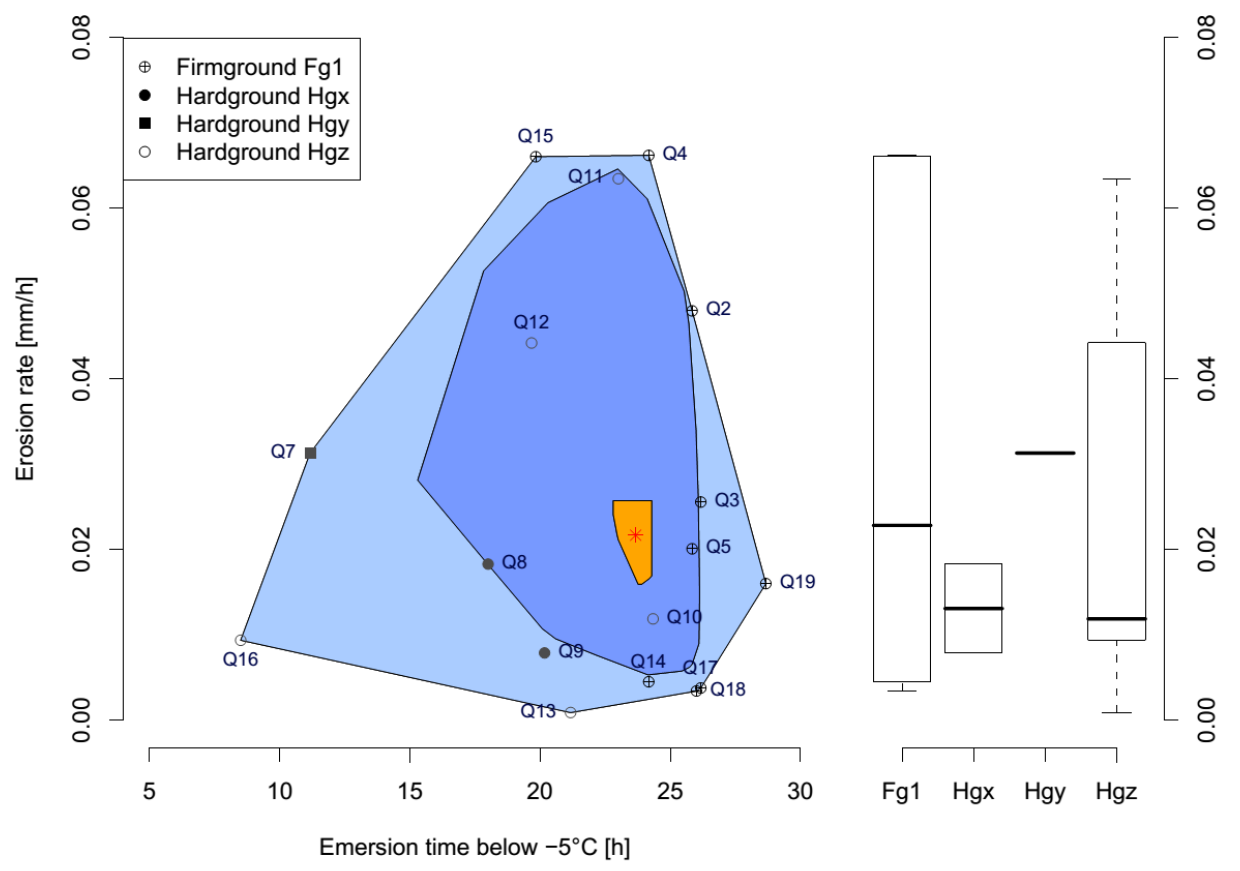

Figure 15. (Left) Bagplot of erosion rate during the time below $-5^{\circ} \mathrm{C}$. The centre bag contains $50 \%$ of the data points and the external bag is the boundary between inliers and outliers (Rousseeuw et al., 1999). Q06 is outside the graph. (Right) boxplot of erosion rate according to the lithology.

Table 2. Results from Moses et al. (2006)'s experiments, expressed in arbitrary unit (base 100 for chalk) of relative importance for each process driving platform lowering: they have been normalized to mean chalk values. The investigations of each process is based on different experiments thus the data do not allow to compare the efficiency of each process (Wetting and drying; Frost shattering; Abrasion). On the contrary it allows comparing the response of each lithology to a same erosion process. Chalk is clearly more prone to erode than the other lithologies studied. Cristalline rocks and hard limestones usually respond $\mathbf{5}$ to $\mathbf{1 0}$ times less efficiently; there is a notable exception for limestones responding only twice less to frost than chalk.

\begin{tabular}{lrrr}
\hline & Wetting & Frost & \\
Sample & Drying & weathering & Abrasion \\
\hline Cristalline rocks & 11.0 & 7.8 & 16.1 \\
Hard limestones & 6.5 & 46.6 & 21.7 \\
Chalk & 100 & 100 & 100 \\
\hline
\end{tabular}

\section{f. Implications for the long-term evolution of shore platforms: frost shattering vs. the other erosive parameters}

It has been proposed that wave attack is the main driver for cliff/platform erosion (Sallenger et al., 2002; Stephenson and Kirk, 2000b; Sunamura, 1992; Trenhaile, 2000, 2009). Indeed, erosion of cliffs may be as fast as a couple of decimeter per year (Costa et al., 2004; Dewez et al., 2013), while the shore platforms at their toe undergo erosion (e.g., Mortimore et al., 2004; Moses and Robinson, 2011; Stephenson and Kirk, 1996; Trenhaile and Byrne, 1986). It is generally assumed that rates of cliff retreat and shore platform downwearing are dynamically coupled (de Lange and Moon, 2005; Sunamura, 1992). If it were not the case, sea wave energy would progressively diminish on the platform with the shallowing water depth and eventually die out before reaching the cliff toe. Active cliff retreat necessarily implies that platforms lower at the same time (e.g., Trenhaile, 2000; Walkden and Dickson, 2008).

Beyond first order, there is much debate in the scientific community on the hierarchy of the various processes driving the evolution of sea cliff/shore platform systems. In addition to waves (i), tides (ii) act as platform humidity regulator influencing wetting and drying cycles and chemical weathering cycles (e.g., Kanyaya and Trenhaile, 2005; Stephenson and Kirk, 2000a). Kanyaya and Trenhaile (2005) have shown with tidally regulated humidity cycles that drying duration is prevails over wetting. It results that 
the higher platform is more exposed to this agent than the lower platform. However, the quantitative effect of weathering in nature is not well quantified. (iii) Biological erosion has been the topic of a limited literature, mostly in chalk environments and/or temperate regions of north-western Europe (e.g., Andrews and Williams, 2000; Naylor et al., 2012; Nesteroff and Mélières, 1967). Current studies are very localised and are far from giving a global view of the erosive, or protective, role of living organisms on the platform. At a macroscopic level what can be said is this: along the chalk coasts of the English Channel, all these competing processes, whatever their hierarchy, result in a linear coastline associated with a relatively smooth plat form, indicating that there are little lateral variations in their overall effect.

The data presented in this paper show that, along with the other driving processes, frost shattering should be accounted for in platform erosion even under temperate climates; at the study site, it once accounted for 20 to $25 \%$ of the expected total annual erosion rate during 10 particularly cold days. As observed, frost shattering may be effective across the intertidal platform so long as frost periods may apply for more than two hours at a time. Hence, this process can lower the platform parallel to itself for most of its width and maintain a steady platform gradient above a certain elevation. On the contrary, frost cannot explain vertical erosion below the lowest tide level mark. So, if frost shattering was the sole and only erosive process acting on the shore, the platform would shallow progressively and would eventually stop cliff base erosion.

\section{Conclusions}

A data set of rock spalling scars characteristics, attributed to frost brecciation, was collected at Mesnil Val, a chalky shore platform in the macro-tidal environment of the English Channel. Despite being bathed by the warm Gulf Stream currents, the coast experiences occasional freezing conditions. Our observations indicate that frost cycles are responsible for a platform lowering of about $0.8 \pm 0.5 \mathrm{~mm}$ during the harsh 2008-2009 winter; that is about 20 to $25 \%$ of the annual vertical erosion rate expected under Sunamura's constant slope cliff-platform erosion model. Platform conditions were analysed with descriptive statistics and erosion rates compared for different platform elevation and position, different lithological facies and freezing cycle duration. Despite the average platform erosion scatter harder chalks suffered more. Morphogenic effects start to occur with a minimum of 10 frost cycles below seawater freezing temperatures, and for durations comprised between 2 and 3.5 hours which is shorter than discussed in earlier literature.

\section{Acknowledgements}

We thank Jérôme Jourde (Cellule de Suivi du Littoral Normand CSLN Le Havre) for fauna determination. This work benefited from funding by BRGM (internal research project EVOLGEOM and Dev-ESCARP coordinated by TD) and the French SHOM/INSU RELIEFS program ("rocky coast erosion: from observation to modeling", coordinated by VR). VR benefited from a 6-months grant from CNRS. MesnilVal is part of Dynalit National Observation Service (http://www.dynalit.fr/).

\section{References}

Aarseth I, Fossen H. 2004. A Holocene lacustrine rock platform around Storavatnet, Osterøy, western Norway. The Holocene 14 : 589-596. DOI: 10.1191/0959683604hl736rp

Andrews C, Williams RBG. 2000. Limpet erosion of chalk shore platforms in southeast England. Earth Surface Processes And Landforms 25 : 1371-1381.

Bristow R, Mortimore R, Wood C. 1997. Lithostratigraphy for mapping the chalk of southern England. Proc. Geol. Assoc. 108 : 293-315.

Costa S, Delahaye D, Freiré-Diaz S, Davidson R, Di Nocera L, Plessis E. 2004. Quantification of the Normandy and Picardy chalk cliff retreat by photogrammetric analysis. In Coastal Chalk Cliff Instability , Mortimore RN and Duperret A (eds). Geological Society, London, Engineering Geology special Publication; $139-148$.

Costa S, Gourmelon F, Augris C, Clabaut P, Latteux B. 2005. Apport de l'approche systémique et pluridisciplinaire dans l'étude du domaine littoral et marin de la Seine-Maritime (France). Norois. Environnement, aménagement, société : 91-108. DOI: 10.4000/norois.534 
Daigneault M, Bouchardon J-L, Guy B. 2004. Coastal cliff erosion vulnerability on the Canadian east coast (Baie des Chaleurs area): a multi-parameter visualization tool. In Coastal Chalk Cliff Instability , Mortimore RN and Duperret A (eds). London; 149-167.

Delunel R, van der Beek PA, Carcaillet J, Bourles DL, Valla PG. 2010. Frost-cracking control on catchment denudation rates: Insights from in situ produced Be-10 concentrations in stream sediments (Ecrins-Pelvoux massif, French Western Alps). Earth and Planetary Science Letters 293 : 72-83. DOI: 10.1016/j.epsl.2010.02.020

Dewez TJB, Rohmer J, Closset L. 2007. Laser survey and mechanical modelling of chalky sea cliff collapse in Normandy, France. In Landslides And Climate Change: Challenges And Solutions ,. Taylor and Francis: London; 281-288.

Dewez T, Rohmer J, Regard V, Cnudde C. 2013. Probabilistic coastal cliff collapse hazard from repeated terrestrial laser surveys: case study from Mesnil Val (Normandy, northern France). In: Conley, D.C., Masselink, G., Russell, P.E. and O'Hare, T.J. (eds.), Proceedings 12th International Coastal Symposium (Plymouth, England), Journal of Coastal Research Special Issue No. 65 : 702-707.

Dornbusch U, Robinson DA. 2011. Block removal and step backwearing as erosion processes on rock shore platforms: a preliminary case study of the chalk shore platforms of south-east England. Earth Surface Processes and Landforms 36 : 661-671. DOI: 10.1002/esp.2086

Duperret A, Genter A, Martinez A, Mortimore RN. 2004. Coastal chalk cliff instability in NW France: role of lithology, fracture pattern and rainfall. In Coastal Chalk Cliff Instability, Mortimore RN and Duperret A (eds). London; 33-55.

Duperret A, Mortimore RN, Pomerol B, Genter A, Martinez A. 2002. L'instabilité des falaises de la Manche en Haute-Normandie. Analyse couplée de la lithostratigraphie, de la fracturation et des effondrements. Bull. Inf. Bass. Paris $39: 6-26$.

Duperret A, Raimbault C, Le Gall B, Authemayou C, Van Vliet-Lanoe B, Regard V, Dromelet E, Vandycke $S$. in press. High-resolution onshore-offshore morpho-bathymetric records of modern chalk and granitic shore platforms in NW France. Comptes Rendus Geoscience

Duperret A, Taibi S, Mortimore RN, Daigneault M. 2005. Effect of groundwater and sea weathering cycles on the strength of chalk rock from unstable coastal cliffs of NW France. Engineering Geology $\mathbf{7 8}$ : 321.

Harris WB, Ralph KJ. 1980. Coastal engineering problems at Clacton-on-Sea, Essex. Quarterly Journal of Engineering Geology 13 : 97-104.

Kanyaya JI, Trenhaile AS. 2005. Tidal wetting and drying on shore platforms: An experimental assessment. Geomorphology $70: 129$.

De Lange WP, Moon VG. 2005. Estimating long-term cliff recession rates from shore platform widths. Engineering Geology 80 : 292.

Lautridou J, Ozouf J. 1982. Experimental Frost Shattering - 15 Years of Research at the Centre-DeGeomorphologie-Du-Cnrs. Progress in Physical Geography 6 : 215-232. DOI: $10.1177 / 030913338200600202$

Lautridou JP, Letavernier G, Lindé K, Etlicher B, Ozouf JC. 1983. Porosity and frost susceptibility of flints and chalk: laboratory experiments, comparison of "glacial" and "periglacial" surface texture of flint materials, and field investigations. presented at the 4th international flint symposium. Brighton Polytechnic. 10-15 pp.. April

Lyard F, Lefevre F, Letellier T, Francis O. 2006. Modelling the global ocean tides: modern insights from FES2004. Ocean Dynamics $56: 394-415$.

Matsuoka N, Murton J. 2008. Frost weathering: recent advances and future directions. Permafrost and Periglacial Processes 19 : 195-210. DOI: 10.1002/ppp.620 
Matthews JA, Dawson AG, Shakesby RA. 1986. Lake shoreline development, frost weathering and rock platform erosion in an alpine periglacial environment, Jotunheimen, southern Norway. Boreas $15: 33-$ 50.

Mortimore RN, Lawrence J, Pope D, Duperret A, Genter A. 2004. Coastal cliff geohazards in weak rock: the UK Chalk cliffs of Sussex. In Coastal Chalk Cliff Instability, Mortimore RN and Duperret A (eds). Geological Society, London, Engineering Geology special Publication; 3-31.

Mortimore RN, Pomerol B. 1987. Correlation of the upper cretaceous white chalk (Turonian to Campanian) in the Anglo-Paris basin. Proceeding of the Geologist's Association 98 : 97-143.

Mortimore RN, Wood CJ, Gallois RW. 2001. British upper Cretaceous stratigraphy. Geological conservation review series 23

Moses CA, Robinson DA, Williams RBG, Marques FMSF. 2006. Predicting rates of shore platform downwearing from rock geotechnical properties and laboratory simulation of weathering and erosion processes. In Europeran Shore Platform Dynamics , . 19-37.

Moses C, Robinson D. 2011. Chalk coast dynamics: Implications for understanding rock coast evolution. Earth-Science Reviews 109 : 63-73. DOI: 10.1016/j.earscirev.2011.08.003

Murton JB. 1996. Near-surface brecciation of chalk, isle of thanet, south-east England: a comparison with ice-rich brecciated bedrocks in Canada and Spitsbergen. Permafrost and Periglacial Processes 7 : 153-164. DOI: 10.1002/(SICI)1099-1530(199604)7:2<153::AID-PPP215>3.0.CO;2-7

Murton JB, Coutard J-P, Lautridou J-P, Ozouf J-C, Robinson DA, Williams RBG. 2001. Physical modelling of bedrock brecciation by ice segregation in permafrost. Permafrost and Periglacial Processes 12 : 255-266. DOI: 10.1002/ppp.390

Murton JB, Peterson R, Ozouf J-C. 2006. Bedrock Fracture by Ice Segregation in Cold Regions. Science 314 : 1127-1129. DOI: 10.1126/science.1132127

Naylor LA, Coombes MA, Viles HA. 2012. Reconceptualising the role of organisms in the erosion of rock coasts: A new model. Geomorphology 157-158 : 17-30. DOI: 10.1016/j.geomorph.2011.07.015

Naylor LA, Stephenson WJ. 2010. On the role of discontinuities in mediating shore platform erosion. Geomorphology $114: 89$.

Nesteroff WD, Mélières F. 1967. L'érosion littorale du pays de Caux. Bull Soc. Géol. Fr. 7 : 159-169.

Prick A. 1995. Dilatometrical behaviour of porous calcareous rock samples subjected to freeze-thaw cycles. CATENA 25 : 7-20. DOI: 10.1016/0341-8162(94)00038-G

Prick A. 1997. Critical Degree of Saturation as a Threshold Moisture Level in Frost Weathering of Limestones. Permafrost and Periglacial Processes 8 : 91-99. DOI: 10.1002/(SICl)10991530(199701)8:1<91::AID-PPP238>3.0.CO;2-4

Regard V, Dewez T, Bourlès DL, Anderson RS, Duperret A, Costa S, Leanni L, Lasseur E, Pedoja K, Maillet GM. 2012. Late Holocene seacliff retreat recorded by $10 \mathrm{Be}$ profiles across a coastal platform: Theory and example from the English Channel. Quaternary Geochronology 11 : 87-97. DOI: 10.1016/j.quageo.2012.02.027

Regard V, Dewez TJB, Cnudde C, Hourizadeh N. 2013. Coastal chalk platform downwearing modulated by step backwearing and debris shielding: example from Normandy and Picardy (northern France). In: Conley, D.C., Masselink, G., Russell, P.E. and O'Hare, T.J. (eds.), Proceedings 12th International Coastal Symposium (Plymouth, England), Journal of Coastal Research Special Issue No. 65 : 16921697.

Robinson DA, Jerwood LC. 1987a. Frost and Salt Weathering of Chalk Shore Platforms Near Brighton, Sussex, Uk. Transactions of the Institute of British Geographers 12 : 217-226. DOI: 10.2307/622529 
Robinson DA, Jerwood LC. 1987b. Sub-aerial weathering of chalk shore platforms during harsh winters in southeast England. Marine Geology 77 : 1-14.

Rousseeuw PJ, Ruts I, Tukey JW. 1999. The bagplot: A bivariate boxplot. American Statistician 53 : 382-387.

Sallenger AH, Krabill W, Brock J, Swift R, Manizade S, Stockdon H. 2002. Sea-cliff erosion as a function of beach changes and extreme wave runup during the 1997-1998 El Nino. Marine Geology 187 : 279297.

Senfaute G, Duperret A, Lawrence JA. 2009. Micro-seismic precursory cracks prior to rock-fall on coastal chalk cliffs : a case study at Mesnil-Val, Normandie, France. Natural Hazards and Earth System Sciences 9 : 1625-1641.

Stephenson WJ, Kirk RM. 1996. Measuring erosion rates using the micro-erosion meter: 20 years of data from shore platforms, Kaikoura Peninsula, South Island, New Zealand. Marine Geology 131 : 209218.

Stephenson WJ, Kirk RM. 2000a. Development of shore platforms on Kaikoura Peninsula, South Island, New Zealand - II: The role of subaerial weathering. Geomorphology $32: 43-56$.

Stephenson WJ, Kirk RM. 2000b. Development of shore platforms on Kaikoura Peninsula, South Island, New Zealand - Part one: The role of waves. Geomorphology $32: 21-41$.

Sunamura T. 1992. Geomorphology of Rocky Coasts . John Wiley \& Sons: Chichester, UK

Trenhaile AS. 2000. Modeling the development of wave-cut shore platforms. Marine Geology 166 : 163.

Trenhaile AS. 2009. Modeling the erosion of cohesive clay coasts. Coastal Engineering $56: 59-72$.

Trenhaile AS, Byrne M-L. 1986. A Theoretical Investigation of the Holocene Development of Rock coasts, with Particular Reference to Shore Platforms. Geografiska Annaler 68 A : 1-14.

Trenhaile AS, Rudakas PA. 1981. Freeze-thaw and shore platform development in Gaspe, Quebec. Geographie Physique et Quaternaire $35: 171-181$.

Walkden M, Dickson M. 2008. Equilibrium erosion of soft rock shores with a shallow or absent beach under increased sea level rise. Marine Geology 251 : 75-84. 